\title{
Effects of human land-use on the global carbon cycle during the last 6000 years
}

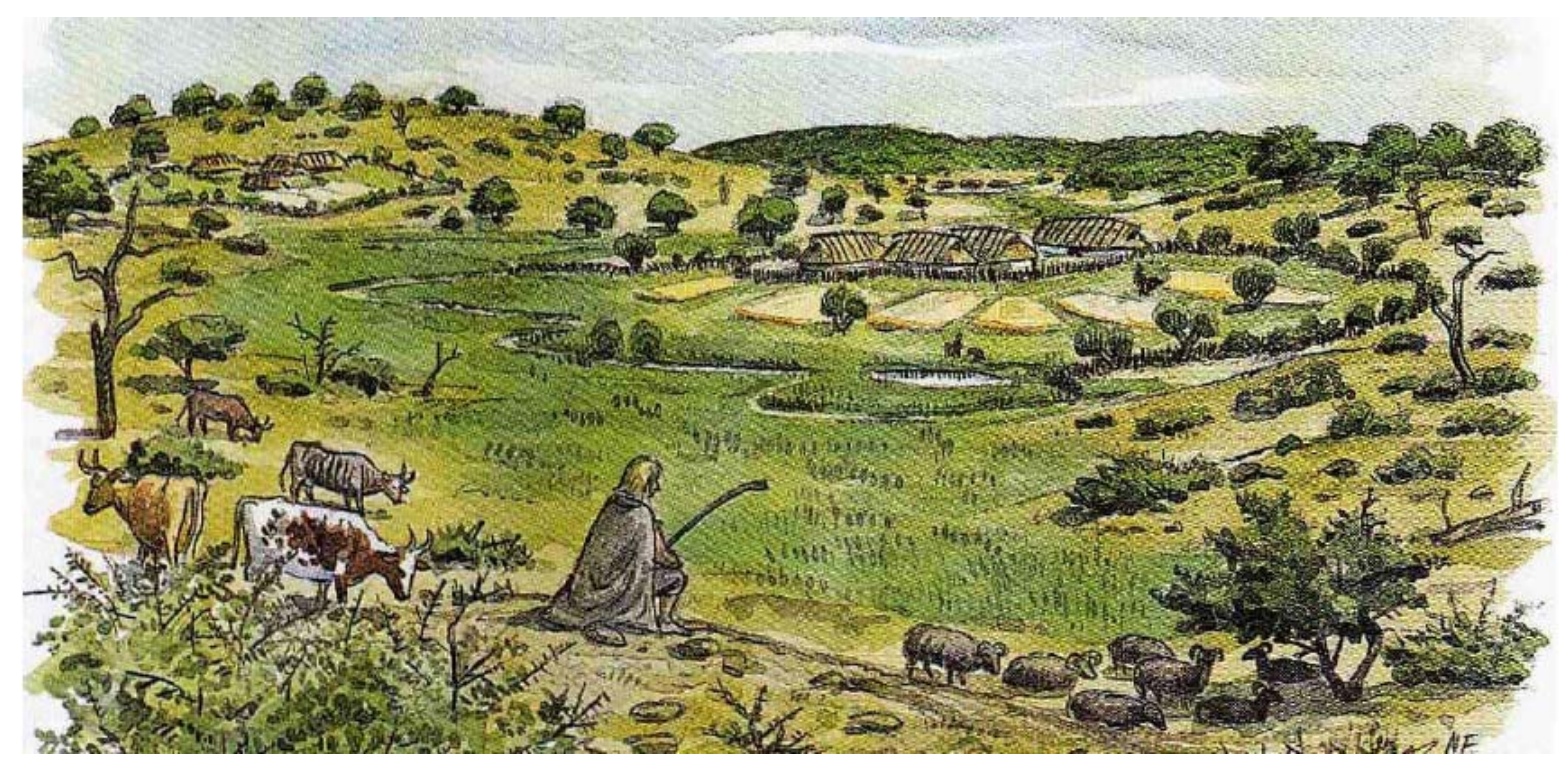

Scania landscape by $A D 1000$ (aquarelle by Nils Forshed)

\section{Jörgen Olofsson}

2006

Geobiosphere Science Centre

Physical Geography and Ecosystems Analysis

Lund University

Sölvegatan 12

S-223 62 Lund

Sweden 

Effects of human land-use on the global carbon cycle during the last 6000 years

By Jörgen Olofsson, 2006

Supervisor: Thomas Hickler

Master Degree-thesis

Geobiosphere Science Centre,

Physical Geography and Ecosystem analysis,

Lund University

Sweden 



\section{ABStRACT}

Humanity has become a major actor within the Earth system, particularly through transforming large parts of the land surface and by altering the gaseous composition of the atmosphere. Deforestation for agricultural purposes started thousands of years ago, which might have resulted in a detectable human influence on climate much earlier than the industrial revolution.

This study presents a first attempt to estimate dynamic changes in anthropogenic carbon fluxes over the last 6000 years. A global gridded data set on the spread of permanent and nonpermanent agriculture over this time period was developed and integrated within the LundPotsdam-Jena Dynamic Global Vegetation Model (LPJ-DGVM). The model was run with and without human land-use, and the differences in terrestrial carbon pools were calculated as an estimate of anthropogenic carbon release to the atmosphere.

The modelled total carbon release during the industrial period (1850-1998) was 162 gigatons of carbon (GtC), of which $36 \mathrm{GtC}$ originated from non-permanent agriculture. For preindustrial times (6000 BP until AD 1850), human-related carbon release was 79 GtC from permanent agriculture and an additional $35 \mathrm{GtC}$ as a result of non-permanent agriculture. The modelled total carbon release was considerably lower than would be required for a substantial influence on the climate system.

Keywords: human land-use, dynamic global vegetation model (DGVM), deforestation, agriculture, carbon cycle, Holocene 



\section{POPULÄRVETENSKAPLIG SAMMANFATTNING}

Människan har blivit en viktig aktör inom systemet jorden, bland annat genom en betydande omvandling av stora landarealer och en stor påverkan på atmosfärens sammansättning. En omfattande avskogning för jordbruksändamål inleddes redan för tusentals år sedan vilket bland annat har medfört ett kolflöde till atmosfären. Enligt en nyligen framlagd hypotes skulle mänsklighetens markanvändning därmed troligen ha orsakat en märkbar klimatpåverkan långt tidigare än med den storskaliga förbränningen av fossila bränslen med resulterande koldioxidutsläpp som inleddes vid industrialiseringens begynnelse för 200 år sedan.

Studien är ett första försök att uppskatta förändringar i antropogena (orsakade av människan) kolflöden på grund av markanvändning under de senaste 6000 åren. En global rutnätsbaserad databas över utvecklingen av permanent och icke-permanent jordbruk för tidsperioden har tagits fram och integrerats i Lund-Potsdam-Jena Dynamic Global Vegetation Model (LPJDGVM), som med klimatdata (temperatur, nederbörd, solinstrålning, koldioxidhalt) mekanistiskt simulerar växtlivet uppdelat i vegetationstyper. Modellen kördes under 6000 år såväl med som utan den globala databasen över markanvändning. Skillnaden i vegetationsoch markkollager mellan de två körningarna beräknades som en uppskattning av nettokolflödet till atmosfären på grund av mänsklig markanvändning.

Det modellerade nettokolflödet orsakat av markanvändning under industrialiseringen (18501998) var 162 gigaton kol (GtC), av vilka 36 GtC var ett resultat av icke-permanent jordbruk. Som jämförelse uppskattas kolflödet från förbränning av fossila bränslen under samma tid till 262 GtC. Under förindustriell tid (6000 år före nutid till år 1850) var det modellerade nettokolflödet 79 GtC från permanent jordbruk och ytterligare 35 GtC från icke-permanent jordbruk. Nettokolflödet orsakat av förindustriell markanvändning var betydligt lägre än vad som skulle ha krävts för att ha en märkbar inverkan på det globala klimatsystemet.

Nyckelord: markanvändning, dynamisk global vegetationsmodell (DGVM), avskogning, jordbruk, kolcykeln, holocen 



\section{TABLE OF CONTENTS}

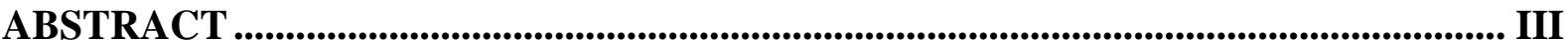

POPULÄRVETENSKAPLIG SAMMANFATTNING ................................................... V

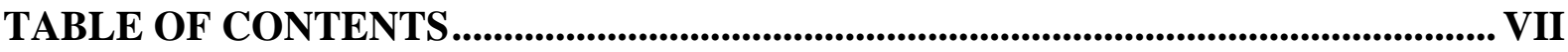



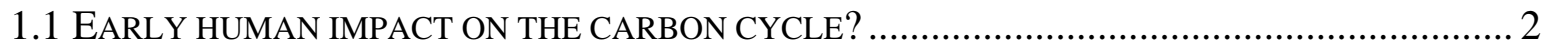

1.2 ESTIMATING CARBON RELEASE FROM HUMAN LAND-USE .......................................... 4

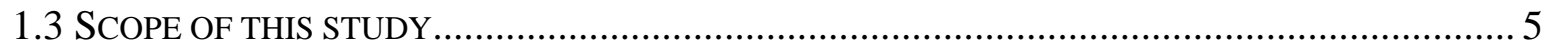





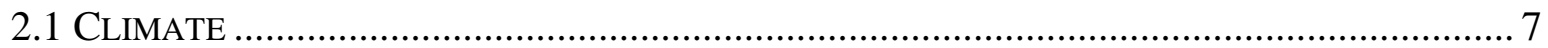

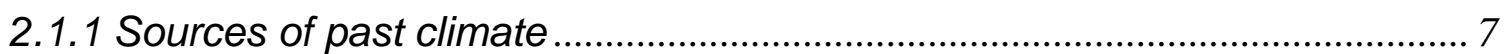

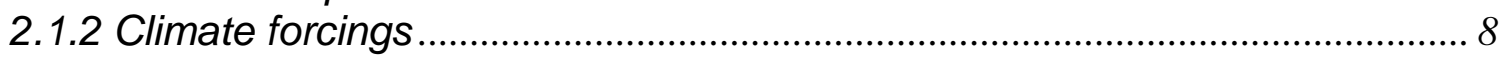



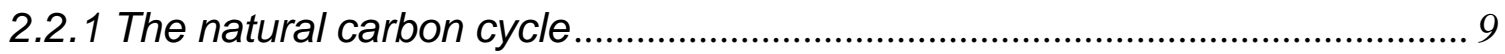

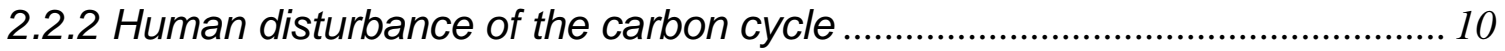

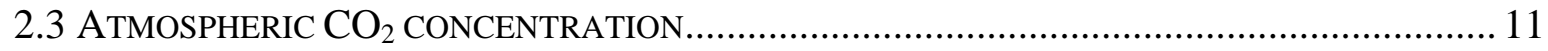

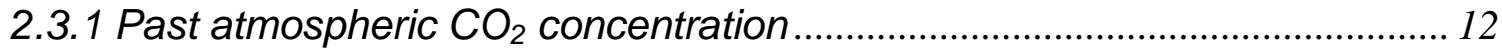

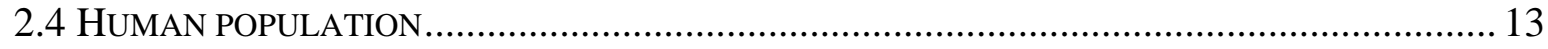



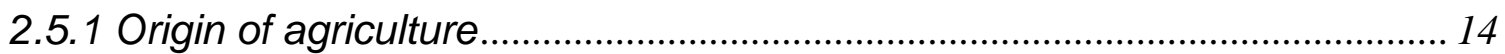

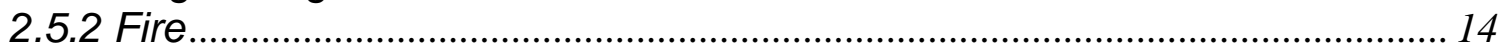

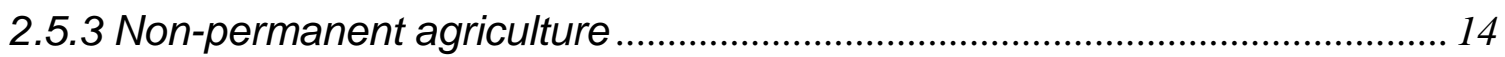

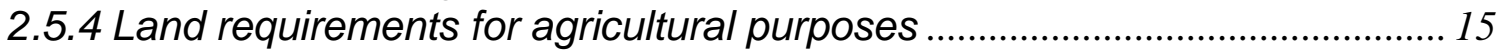

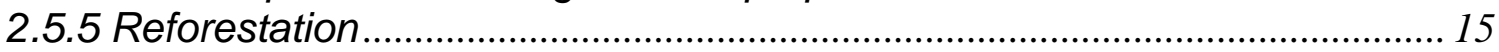

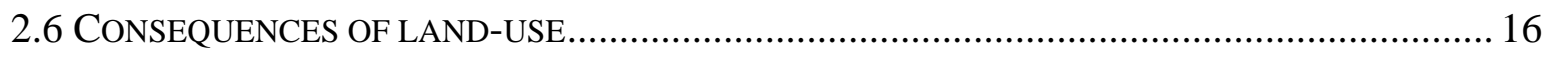



3.1 The Lund-Potsdam-Jena Dynamic Global Vegetation Model............................. 17

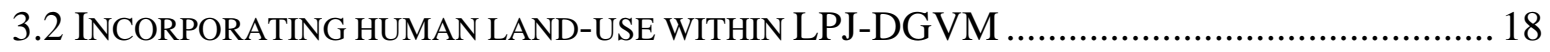

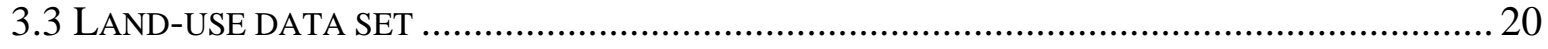



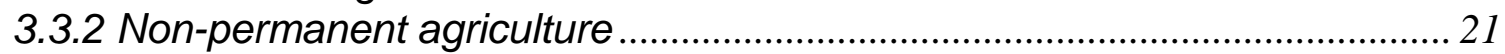

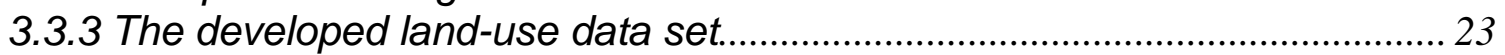

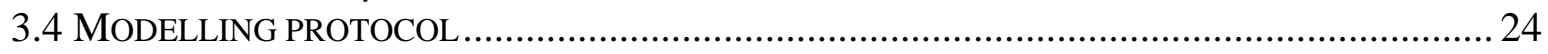

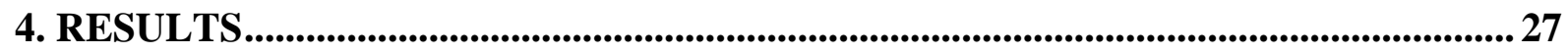



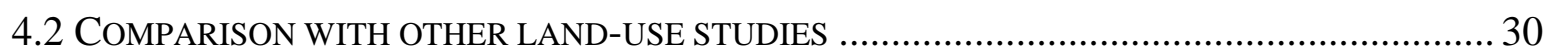



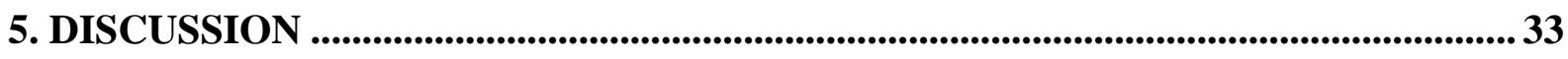

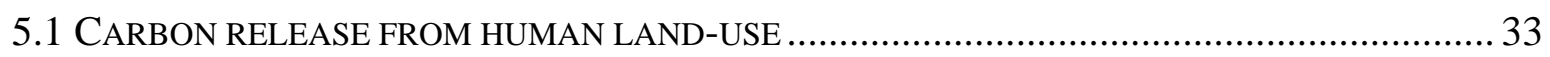

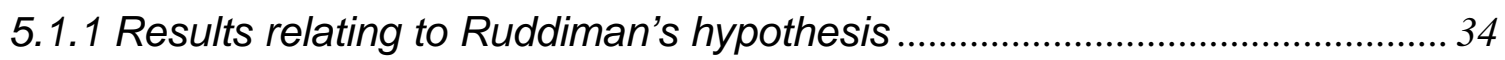






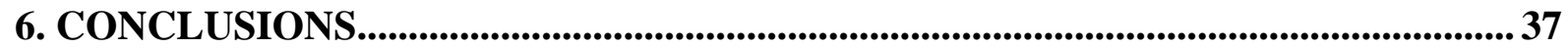

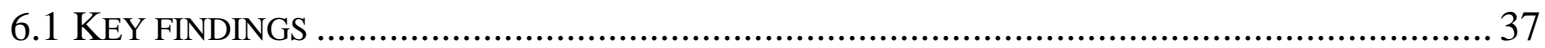



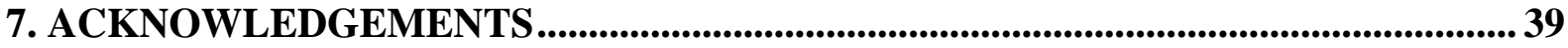

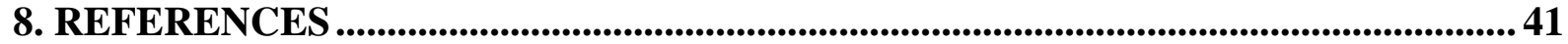



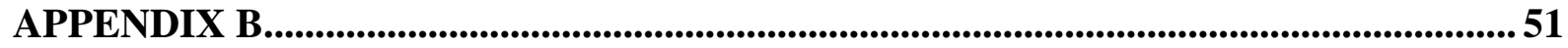






\section{INTRODUCTION}

Earth's climate during the past two million years has been dominated by a cyclic development of long glacial periods interrupted by short warmer interglacials, but also influenced by natural climate fluctuations on shorter time-scales (Bonan 2002). The latest glacial period ended about 11,500 years $\mathrm{BP}^{1}$ and the current interglacial, which has seen an advancement of human beings and civilization all over Earth, is usually named the Holocene (Roberts 1998).

Until today, human activity has altered between a third and a half of Earth's land surface by especially cropping, pasture, forestry and urbanisation (Vitousek et al. 1997), with consequences for key biogeochemistry cycles, changing the atmospheric composition and resulting in considerable modifications of ecosystems (Foley et al. 2005). Land-use changes result in biogeophysical climatic effects through modifications of surface albedo and roughness (Brovkin et al. 2006) and biogeochemical effects through, e.g., altering the vegetation and soil carbon pools (Houghton \& Goodale 2004), as well as modifying the hydrological cycle (Gordon et al. 2005), which influences atmospheric greenhouse gas levels and the global climate (Foley et al. 2003).

Deforestation for agriculture and pasture is a major driver of the accelerating land transformation (Williams 2000), and the reduction in Earth's forests has followed the rise of human history since the beginning of agricultural and pastoral development thousands of years ago (Turner et al. 1990). Domestic fuel need, shipbuilding and charcoal consuming metal melting are additional driving forces behind the increased forest clearing over the centuries (Williams 2000). An increasing human population and a civilization with technology advances within agriculture, forestry, mining and trade have caused substantial changes in forest vegetation (Williams 2000). Klein Goldewijk (2001) estimated a loss of natural forest/woodland areas as a result of human activity of $6 \%$ by $1700,14 \%$ by 1850 and $34 \%$ by 1990 of the natural land cover (Figure 1).

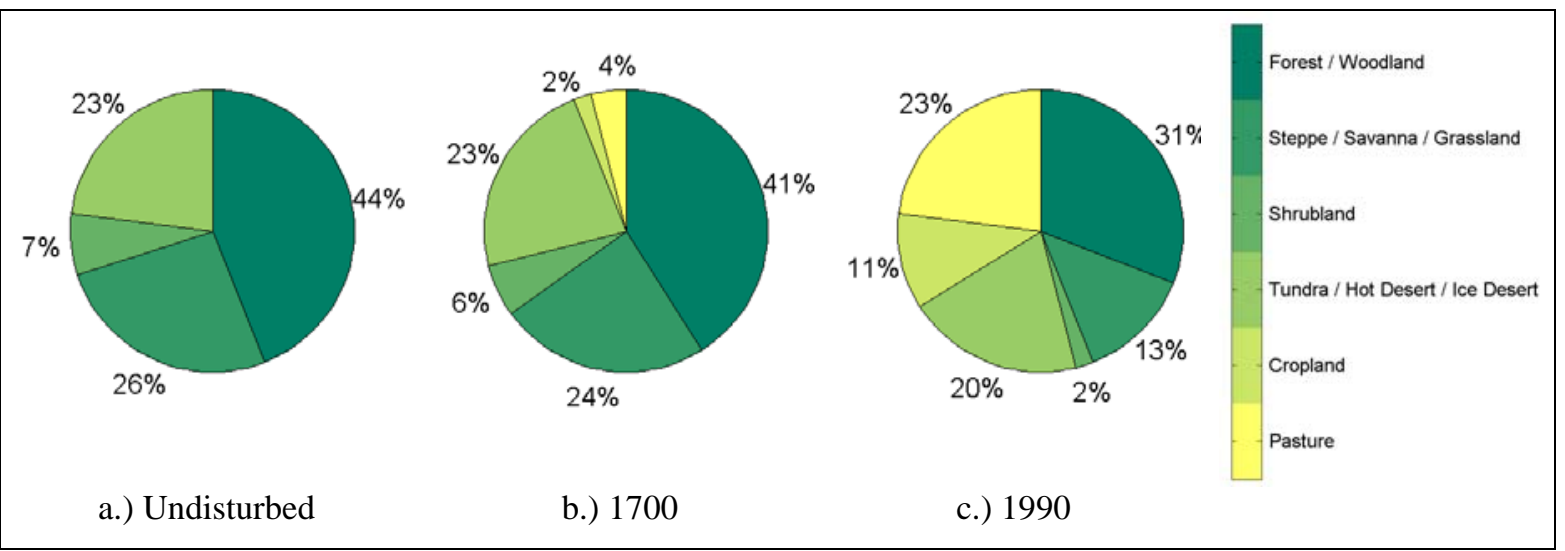

Figure 1. Estimated shares of global land cover classes; a.) undisturbed land cover (modelled potential natural vegetation simulated with a modified version of the BIOME model [original version described by Prentice $e t$ al. 1992]), b.) land-use by 1700, c.) land-use by 1990. Adapted from Klein Goldewijk (2001).

Today, most temperate forests in Europe and China, as well as the monsoon and dry forests in India, have disappeared (Williams 2003). Clearance of tropical rain forests have accelerated

\footnotetext{
${ }^{1}$ BP means Before Present, which relates to the year 1950, established as the benchmark year for scientific dating as this was when the calibration curves for the well-known carbon-14 dating were established.
} 
since the 1950s and accounts for most of the present land-use-related emissions (Malhi et al. 2002), while Europe and North America currently experience a small net-expansion of forests following a farmland reduction as a result of a stabilised population size and increased crop returns (Williams 2000).

There is a growing concern regarding human-induced climate change as a result of the rapidly increasing levels of atmospheric greenhouse gases such as carbon dioxide $\left(\mathrm{CO}_{2}\right)$ and methane $\left(\mathrm{CH}_{4}\right)$, primarily caused by fossil fuel use (Prentice et al. 2001), and to a lesser but important degree by human land-use, especially deforestation (Houghton 2003a). The consequences of changing temperatures along with shifting wind and precipitation patterns (Trenberth et al. 2003) as well as more sever weather extremes (Easterling et al. 2000) are difficult to estimate, but are likely to result in considerable impacts on global ecosystems and human society (McCarthy et al. 2001; Karl \& Trenberth 2003). The starting point for anthropogenic influence on climate is usually said to be the onset of large-scale fossil fuel burning by the industrial revolution 200 years ago, and the present era has been named the Anthropocene (Crutzen \& Stoermer 2000).

\subsection{Early human impact on the carbon cycle?}

Ruddiman (2003) recently raised a sharply contrasting idea: the Anthropocene actually begun much earlier, with forest clearing for cultivation in Eurasia starting $8000 \mathrm{BP}$ resulting in $\mathrm{CO}_{2}$ emissions, and rice irrigation in Asia 5000 BP causing increasing $\mathrm{CH}_{4}$ levels (Ruddiman \& Thomson 2001). This thought thus links early human land-use to a pre-industrial change in the atmospheric composition. Consequently, according to Ruddiman, this should explain the Holocene anomaly compared to trends of atmospheric greenhouse gases for the three previous interglacials, observed in ice core measurements (Figure 2).

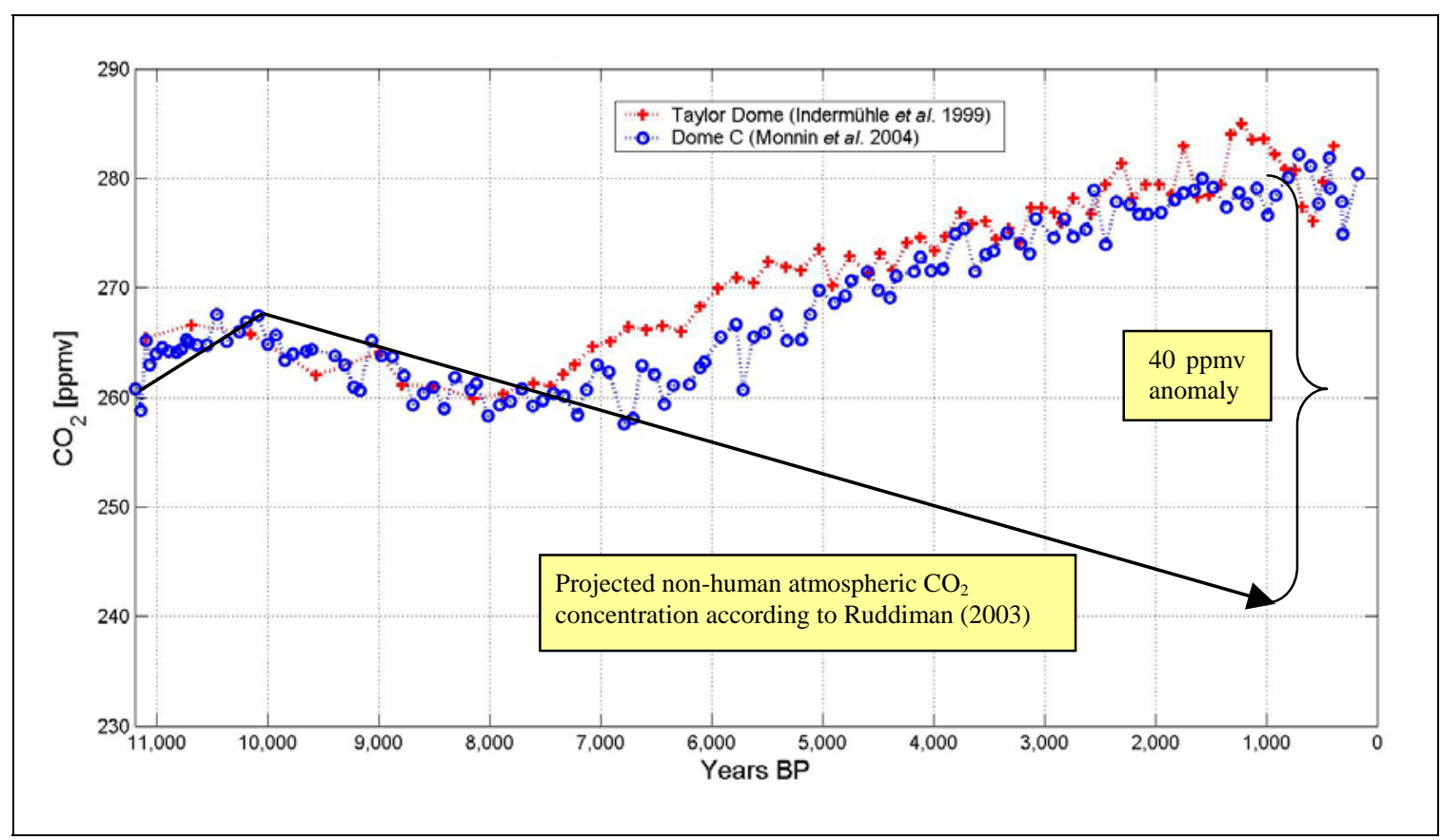

Figure 2. Atmospheric $\mathrm{CO}_{2}$ level from 11,200 BP until 170 years BP. Ice core measurements adapted from Indermühle et al. (1999) and Monnin et al. (2004), compared with the projected, non-human influenced atmospheric $\mathrm{CO}_{2}$ development according to Ruddiman (2003). [ppmv] 
According to Ruddiman, the anomaly consists of a $\mathrm{CO}_{2}$ increase of 40 parts per million volume (ppmv) until pre-industrial times (Figure 2), as well as a $\mathrm{CH}_{4}$ rise of 250 parts per billion volume (not shown), which could have prevented a glaciation at high northern latitudes. The 40 ppmv $\mathrm{CO}_{2}$ corresponds to 250 gigatons of carbon (GtC) of direct human emissions until 2000 BP (Ruddiman 2003), based on calculations ${ }^{2}$ from Indermühle et al. (1999). Human influence on climate would thus have been going on for thousands of years and not, as commonly believed, only since the start of industrialisation two centuries ago.

This novel thought has received considerable attention, including rather critical views, and is being lively debated (e.g., Mason 2004). Joos et al. (2004) performed simulations of terrestrial and atmospheric carbon development during the Holocene, and suggested that a series of natural processes could explain the $\mathrm{CO}_{2}$ rise starting 8000 years ago. They estimated that Ruddiman's hypothesis would mean an early anthropogenic emission of $710 \mathrm{GtC}$ to explain the 40 ppmv $\mathrm{CO}_{2}$ anomaly, as oceans would remove $85 \%$ of the emitted carbon on a millennium timescale. A carbon release of this magnitude is three to four times above previous estimates of land-use emissions during the entire Holocene, including the industrial period (DeFries et al. 1999) and is not consistent with observed ice core $\delta^{13} \mathrm{C}$ records ${ }^{3}$ (Indermühle et al. 1999). Joos et al. (2004) concluded that human-induced land-use emissions might have contributed a maximum of 4-6 ppmv of the pre-industrial $\mathrm{CO}_{2}$ increase.

Other modelling studies also discuss Ruddiman's hypothesis. In one commentary, Crucifix et al. (2005) noted that integration of paleoclimate so-called proxy data (Section 2.1.1) within climate models would be an important way to test early human influence. Claussen et al. (2005) suggested that the three latest interglacials are not an accurate equivalent for the Holocene and concluded that a strong human forcing is not needed to explain the observed Holocene $\mathrm{CO}_{2}$ development. As older ice-core $\mathrm{CO}_{2}$ archives are now available (Siegenthaler et al. 2005), even more doubt has been raised against the uniqueness in the Holocene anomaly; suggesting that natural causes would be sufficient to explain the $\mathrm{CO}_{2}$ development (O’Hare et al. 2005; Broecker \& Stocker 2006).

In response to the critics, Ruddiman (2005a; 2005b; 2005c) has slightly modified the original hypothesis and is now claiming that direct anthropogenic emissions would explain only 14 ppmv (Ruddiman 2005c) of the Holocene $\mathrm{CO}_{2}$ anomaly, corresponding to an emission of slightly less than $200 \mathrm{GtC}$ based on the relationship in Joos et al. (2004). Instead, indirect effects such as preventing northern ice sheet formation, which would cool the climate through positive feedback mechanisms, would explain a major part of the anomaly. Another indirect effect would be a restriction in southern sea-ice advance, which would cut off the carbon exchange between the surface ocean and the atmosphere. Thus, a number of indirect effects would have constrained the $\mathrm{CO}_{2}$ drop seen during the three previous interglaciations.

Thus, the underlying causes for the Holocene atmospheric $\mathrm{CO}_{2}$ development are not fully understood, though several explanations have been presented (e.g., Joos et al. 2004; Wang et al. 2005). Modelling studies of the entire Holocene excluding human land-use show a wide variation in results. Indermühle et al. (1999) estimated a terrestrial release of $195 \pm 40 \mathrm{GtC}$ from $7000 \mathrm{BP}$ to $1000 \mathrm{BP}$, possibly resulting from a colder and drier climate compared to mid-Holocene conditions. Wang et al. (2005) used a model with vegetation-precipitation feedback, applying actual variable solar forcings and atmospheric $\mathrm{CO}_{2}$ forcing. Without land-

\footnotetext{
${ }^{2}$ Indermühle et al. (1999): $195 \mathrm{GtC}<>25$ ppmv; $195 *$ 40/25 * 80\% = 250 (for details, see Ruddiman 2003)

${ }^{3}$ Ice core $\delta^{13} \mathrm{C}$ records are used to trace the carbon source from different carbon reservoirs.
} 
use they found a global terrestrial carbon release from $6000 \mathrm{BP}$ until the end of the preindustrial period of 68-95 GtC. Simulations without land-use by Joos et al. (2004) yielded a terrestrial carbon uptake of 28-75 GtC during the past 6000 years, contradicting the carbon release found in most recent studies (see, e.g., Wang et al. 2005).

\subsection{Estimating carbon release from human land-use}

A variety of methods have been used to estimate the carbon release caused by land-use. The methodology and investigated time period influence the result (see Table 1 for a summary of recent land-use-related studies). One approach is the "book-keeping" method, based on deforestation statistics combined with vegetation and soil carbon approximations (Houghton et al. 1983). Land-use changes are represented as vegetation disturbances with corresponding response curves for each ecosystem. By using this approach, Houghton (1999) estimated a net release of $124 \mathrm{GtC}$ between 1850 and 1990 caused by human land-use, later revised to 134 $\mathrm{GtC}$ for the same time period (Houghton 2003a).

Table 1. Recent land-use-change-related studies covering different time periods, with resulting estimates of global carbon release. [GtC]

\begin{tabular}{lrc}
\hline Study & Time period & Carbon release \\
\hline DeFries et al. (1999) & -1850 & $48-57$ \\
& -1990 & $182-199$ \\
McGuire et al. (2001) & $1920-1992$ & $56-91$ \\
Houghton (2003a) & $1850-1990$ & 134 \\
Ruddiman (2003) & -2000 BP & 250 \\
& -1850 & 320 \\
Levy et al. (2004) & $1700-1990$ & 222 \\
& $1850-1990$ & 173 \\
Campos et al. (2005) & $1700-1990$ & 139 \\
& $1850-1990$ & 98 \\
\hline
\end{tabular}

DeFries et al. (1999) used a global terrestrial carbon cycle model to estimate carbon emissions caused by human-induced land cover change. Existing vegetation cover was derived from satellite $\mathrm{NDVI}^{4}$-data while pre-industrial natural vegetation was simulated based on maps derived from ground-based information or climate-driven models. By comparing the resulting maps the difference in terrestrial carbon was recognized as human-induced land cover change, estimated to have caused an accumulated net carbon loss of 182-199 GtC until 1990. Carbon release from agricultural expansion before 1850 was estimated to 48-57 GtC, based on areas cleared for agriculture by 1850 from Houghton et al. (1983). (Table 1)

Another approach is to use ecosystem models that represent global patterns of land cover and the terrestrial carbon cycle in combination with data sets on human land-use at different times. The models can then be driven with data on existing or historical land-use and with potential natural vegetation cover and carbon dynamics (e.g., Prentice et al. 2000). The difference between the modelled total terrestrial carbon storage with land-use and the results

\footnotetext{
${ }^{4}$ Normalized Difference Vegetation Index (NDVI) $=($ NIR-VIS)/(NIR+VIS)

NIR = Near Infra-red Radiation, wavelength $>0.7 \mu \mathrm{m}$ and VIS = Visible Radiation, wavelength 0.4-0.7 $\mu \mathrm{m}$ Higher positive NDVI-values indicate a more productive vegetation absorbing more VIS (Section 2.2)
} 
obtained with natural vegetation provides an estimate of the carbon release that has been caused by that land-use.

Ramankutty \& Foley (R\&F 1999) estimated fractional cropland on a continuous scale (0$100 \%$ ) based on permanent global cropland areas in 1992, derived from remotely sensed land cover classification and inventory data. Fractional cropland maps back to 1700 were thereafter reconstructed through a land cover change model based on historical population data. Klein Goldewijk (2001) developed a historical global environment database (HYDE) with grid cells influenced by agriculture classified either as cropland or pasture from 1700 until 1990, based on population density as a proxy for agricultural activity, assuming that areas with high population densities have remained so over the investigated time-period.

Several modelling studies based on R\&F or HYDE have been carried out to estimate terrestrial carbon fluxes caused by land-use changes. Applying the R\&F data set, McGuire et al. (2001) included biogeochemical effects in a simulation with four ecosystem models. For land-use alone, the modelled carbon release ranged from 56 to $91 \mathrm{GtC}$ between 1920 and 1992. The large range indicates that fluxes associated with agricultural activity represent a major uncertainty between the models. Levy et al. (2004) applied the R\&F data set into a dynamic global vegetation model together with simulated historical climate (HadCM3, Gordon et al. 2000) and estimated the flux from land-use to $222 \mathrm{GtC}$ for 1700 until 1990, and 173 GtC for 1850 until 1990. Campos et al. (2005) used the HYDE data with cropland and pasture, resulting in a simulated net emission of 98 GtC (1850-1990) and 139 GtC (17001990). (Table 1; see also Section 4.2 and Table 7)

\subsection{Scope of this study}

The objective with the present study is to estimate the development of carbon emissions in the form of $\mathrm{CO}_{2}$ from human land-use through time. In contrast to DeFries et al. (1999), dynamic land-use was considered in the present study. A dynamic global land-use data set with permanent and non-permanent agriculture over the past 6000 years was developed from the literature. Non-permanent agricultural practices, such as slash-and-burn or shifting cultivation, can repeatedly result in release of carbon to the atmosphere without showing a permanent "fingerprint" on the land cover, but the global impact is not known to have been assessed in any other study. The developed land-use data set was used to run the LundPotsdam-Jena Dynamic Global Vegetation Model, LPJ-DGVM (Sitch et al. 2003). The model was run with and without land-use, and the differences in terrestrial carbon pools were calculated to quantify an estimate of anthropogenic impact and greenhouse forcings through land-use during the last 6000 years.

\subsection{Overview}

After these introductory pages, a more detailed background is given for the climate and carbon systems, followed by an overview of the development of humanity, land-use and resulting consequences. The applied method with modifications of the vegetation model and the derivation of the land-use data set is then described in detail. The modelling results are presented with graphs and tables, together with an overview of previous land-use studies. Results and uncertainties are thereafter discussed, followed by a final section where the main conclusions are noted and a few recommendations for future research are given. 



\section{BACKGROUND}

\subsection{Climate}

Earth's climate has varied greatly during the 4.55 billion years of age, with changes occurring on timescales from years up to billions of years (Ruddiman 2001). Global climate has fluctuated also during the Holocene, sometimes rapidly (Mayewski et al. 2004), occasionally abruptly as the so-called 8k-event (Alley \& Ágústsdóttir 2005), with severe consequences for ecosystems and human societies (Berglund 2003). Understanding the historical climate development is crucial in research regarding likely consequences of the expected near-future climate change caused by human activities (Bradley 2000; Jones \& Mann 2004).

During the past two million years there has been a cyclic advance and retreat of glaciers in the Northern Hemisphere with a periodicity of 100,000 years, dominated by long glacial periods interrupted by short warmer interglacials (Bonan 2002). At the Last Glacial Maximum about 21,000 years BP, Earth was on average approximately $5^{\circ} \mathrm{C}$ colder and significantly drier than present climate (Roberts 1998). Thick ice sheets covered an area twice that of the current glaciers and the sea level was about 100 meters lower, resulting in $10 \%$ more continental landmass than today. Terrestrial carbon was considerably lower (931 GtC, 35\% of present potential) and forests covered only one third of the area compared to late Holocene excluding human clearance (Adams \& Faure 1998), as Northern boreal-forested areas were ice covered, while regions south of the ice-cover were mostly steppes and savannas.

\subsubsection{Sources of past climate}

Global instrumental meteorological records are available only for the last 100-150 years (Jones \& Mann 2004). As this is a very short glimpse in Earth's long history, several paleoclimatic so-called proxy-data sources have been developed, including sediments, pollen, ice cores, corals, tree rings and historical archives (Roberts 1998; Brázdil et al. 2005). Combinations of these climate archives have facilitated the reconstruction of historical climate series (e.g., Mann et al. 1998; Jones \& Mann 2004; Moberg et al. 2005).

Pollen preserved in lake mud or peat bogs constitute one source used to reconstruct past vegetation and to determine the underlying controlling factors, such as precipitation and temperature (Bonan 2002). Determination of human activities from pollen diagrams usually involves a combination of evidences, including changes in vegetation composition and grassland indicator species (Ren 2000; Berglund 2003). From vegetation modelling based on pollen data, studies of past landscape openness have been performed, e.g., for southern Sweden (Sugita et al. 1999), for China north of the Yangtze River (Ren \& Beug 2002) and recently on a European level (Mitchell 2005).

Analysing deposited charcoal in stratified sediments from lake and wetlands facilitates temporal studies of past biomass fires (Carcaillet et al. 2002). Vegetation response to past fire events can be identified by combining charcoal records with pollen taxa studies. Relationship changes between fire-adapted and fire-sensitive taxa with fire frequency trends throughout the Holocene have been identified. Through a combination of charcoal and fire reconstruction studies from several locations, an estimate of past regional and global climate change and variability can be realised (Whitlock \& Bartlein 2004). 


\subsubsection{Climate forcings}

Several mechanisms influence Earth's climate: plate tectonics (continental drift), orbital changes, the greenhouse house effect (water vapour, $\mathrm{CO}_{2}, \mathrm{CH}_{4}$, nitrous oxide as well as ozone, halocarbons and carbon compounds with fluorine, chlorine, bromine or iodine), freshwater runoff and thermohaline circulation, solar variability and aerosols (Bonan 2002). Incoming solar radiation is the main driver, controlling temperature, pressure, precipitation, wind and the global weather systems. Received radiation at the surface fluctuates as a result of variations in the precession and tilting angle of Earth's rotational axis, spatially with latitude and temporally with seasons, affecting local, regional and global climate, essential for the cyclic dynamics of global ecosystems (Bonan 2002).

Milankovitch (Hays et al. 1976) identified three main astronomical cycles, eccentricity (100,000/413,000 years cycle), axial tilt (41,000 years) and precession (21,000 years). Combining these cycles produces a complex configuration, amplifying or reducing seasonal and latitudinal differences in solar radiation, which is believed to control the glacialinterglacial cycle (Roberts 1998) together with physical, chemical and biological feedback mechanisms within the climate system (Bonan 2002). According to the Milankovitch theory, weak summer insolation at high latitudes, resulting in reduced summer melting and thus allowing snow and ice sheet accumulation, would increase climate cooling and lead to glacial periods, and the opposite to warmer interglacial periods (Ruddiman 2001).

Variations in volcanism and concentration of sulphate aerosols in the atmosphere (Zielinski 2000), solar irradiance (Beer et al. 2000), greenhouse gases and vegetation cover are additional factors controlling climate. Feedback mechanisms including changes in water vapour content, cloud formation, ocean circulation and ice-albedo also have an important influence on climate (Houghton 2005a). The interrelationships between these forcings and mechanisms are far from being completely understood. Moreover, during the Holocene a human factor has emerged, with increasing agricultural and industrial activities through time. The results are a transformed land cover and a change in the atmospheric composition including rising levels of greenhouse gases, sulphate and soot particles. Thus, humanity has further complicated the research of understanding past, current and future climate (Sagan et al. 1979; Ruddiman 2001).

\section{Land cover and albedo}

Surface properties and land cover, especially vegetation, influence local and regional climates (Bonan 2002). An important parameter is the albedo, the proportion of incoming radiation reflected by the surface. High albedo means that less solar radiation is absorbed resulting in a cooler surface, while a low albedo results in a warmer surface. Snow, deserts and glaciers have the highest albedo values, while vegetation, water and urban surfaces all have low albedo. Land cover changes from forest to agriculture increase the albedo (Vitousek et al. 1997) and reduce the evapotranspiration, which affect local and regional precipitation patterns (Bonan 2002), and by so alters local and regional climate conditions. On a global level, largescale human-induced land cover changes are today believed to influence the global climate system (e.g., Pielke et al. 2002; Pielke 2005).

\section{Greenhouse gases}

Atmospheric greenhouse gases, notably water vapour, $\mathrm{CO}_{2}$ and $\mathrm{CH}_{4}$, absorb $95 \%$ of the longwave radiation emitted from the surface, resulting in a global average net-heating of $31^{\circ} \mathrm{C}$ compared to a situation with no greenhouse gases, making Earth an inhabitable, non-frozen planet (Ruddiman 2001). From climate archives it is known that greenhouse gas levels and 
climate conditions have varied considerably throughout time (Petit et al. 1999). However, it is also recognised that the present $\mathrm{CO}_{2}$ concentration is at a higher level than in at least 650,000 years (Siegenthaler et al. 2005), and today possibly higher than during the last 20 million years (Pearson \& Palmer 2000). Furthermore, the current rapid increase is at least ten times faster than during any period during the last 20,000 years (Prentice et al. 2001).

\subsection{The carbon cycle}

Carbon is a fundamental element for life. Atmospheric $\mathrm{CO}_{2}$ is essential for photosynthesis in plants, where incoming radiation energy is absorbed, and allowing the conversion of $\mathrm{CO}_{2}$ to carbohydrates, providing energy and structural material as well as building blocks for necessary molecules. Through photosynthesis the plants produce oxygen, vital for humans, animals and most living organisms. Moreover, only plants are able to directly convert incoming radiation energy into carbohydrates that through metabolism (respiration) constitute essential energy sources for a majority of all other life forms. Via this energy release and decomposition (respiration of organic matter primarily by fungi and bacteria), carbohydrates are reconverted to $\mathrm{CO}_{2}$, which when released back to the atmosphere closes the biological carbon cycle. (Bonan 2002)

\subsubsection{The natural carbon cycle}

The main pre-human carbon reservoirs and yearly exchange rates are presented in Figure 3.

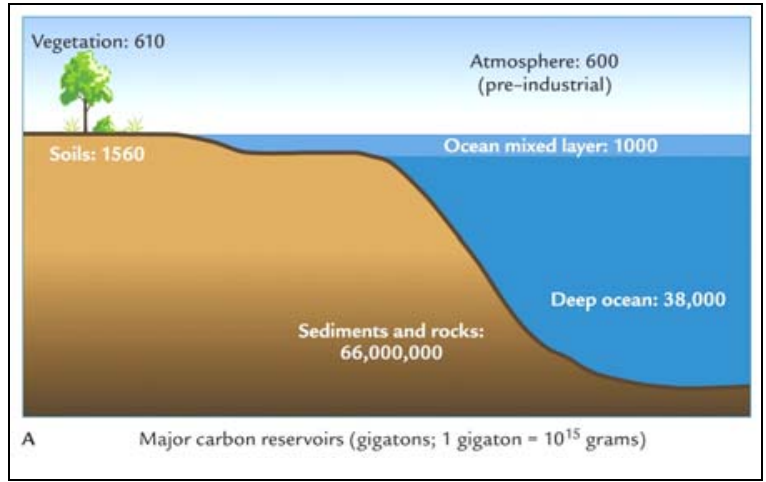

a.)

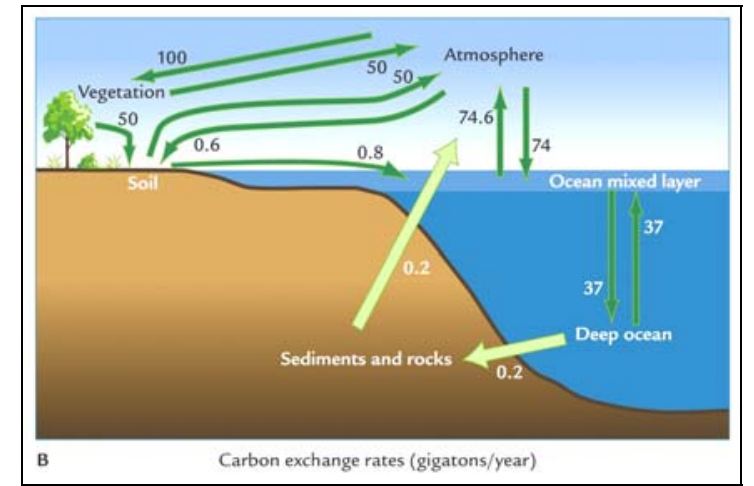

b.)

Figure 3. The natural carbon cycle; a.) major natural carbon reservoirs [GtC], b.) yearly natural carbon exchange rates [GtC/yr]. (From Ruddiman 2001)

Sediments and rocks contain by far most of the carbon, followed by the deep ocean. However, the main yearly carbon exchange paths connect the relatively smaller pools of vegetation, soil, ocean mixed layer and the atmosphere, making these carbon reservoirs and exchanges the most important to understand on shorter time scales. Noteworthy is that the soil contains more than twice the amount of carbon found in living vegetation biomass, while the atmosphere approximately holds as much carbon as the vegetation during the pre-human interglacial time. During glacial times considerably less carbon has been present in both the biosphere (vegetation and soil) and in the atmosphere. The ocean is believed to be the main carbon regulator on this glacial-interglacial timescale, through a transfer of carbon via the exchange between the ocean surface and the atmosphere into the deep ocean. (Ruddiman 2001) 


\subsubsection{Human disturbance of the carbon cycle}

Today the carbon cycle is not natural as a result of extensive human activity. Carbon trapped by the biosphere in pre-historical times and then transferred to the geological reserves is now being quickly returned to the atmosphere through fossil fuel combustion, resulting in a rapidly increasing $\mathrm{CO}_{2}$ level (Prentice et al. 2001). Furthermore, clearing of forests for agricultural purposes results in a reduction in vegetation and soil carbon (Houghton 1999; Paul et al. 2002) and an increase in atmospheric $\mathrm{CO}_{2}$ (Houghton 2003a). On the other hand, abandoning agricultural land allows forest re-growth and a re-accumulation of carbon in biomass and soil, which reduces atmospheric $\mathrm{CO}_{2}$ (see also Section 2.5.5).

\section{Carbon budget 1850-2000}

Human activities such as fossil fuel burning and land-use have disturbed the natural carbon balance. For the last 150 years the carbon pool changes are relatively well known (Figure 4).

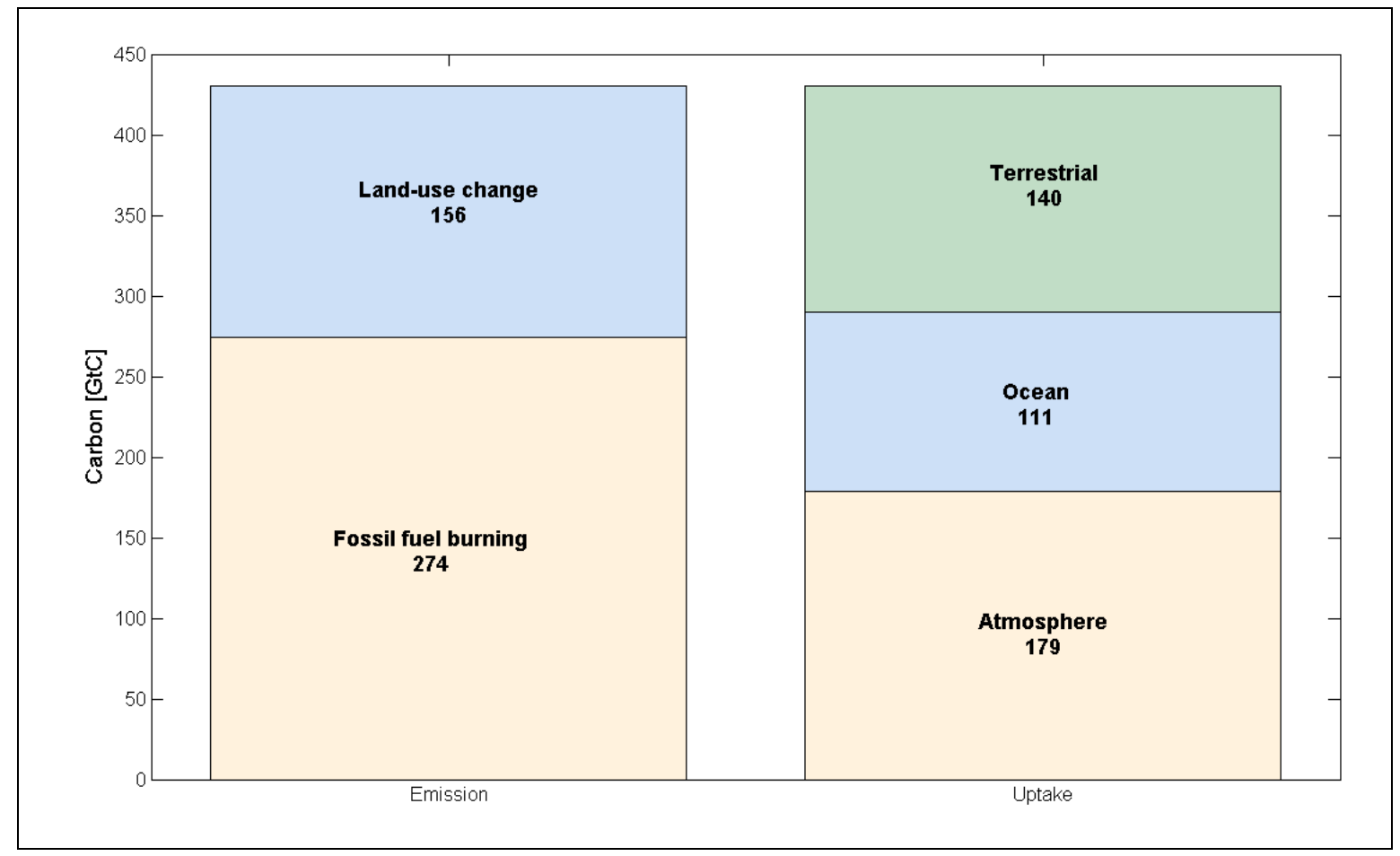

Figure 4. Estimated balance between carbon emissions and uptake from 1850 until 2000. [GtC]

Stored fossil fuel has decreased by $274^{5}$ GtC (Marland et al. 2006), while the estimated loss related directly to human land-use is 156 GtC (Houghton 2003a). Atmospheric carbon has increased with $179^{6} \mathrm{GtC}$ based on Etheridge et al. (1996) and Keeling \& Whorf (2005), and ocean carbon by $111^{7} \mathrm{GtC}$ based on House et al. (2002), all numbers for the period 1850 until 2000. The remaining $140 \mathrm{GtC}$ is believed to have been absorbed by the terrestrial biosphere through a mixture of processes such as vegetation re-growth on abandoned farmland, land management practises, fertilizing effects caused by increased atmospheric $\mathrm{CO}_{2}$ levels and nitrogen deposits, and climate change effects such as increasing growing seasons at higher latitudes (House et al. 2002).

\footnotetext{
${ }^{5}$ 1850-1998: 262 GtC (Marland et al. 2006)

${ }^{6}$ 1850: 285.2 ppmv (Etheridge et al. 1996) and 2000: 369.5 ppmv (Keeling \& Whorf 2005). Difference 84.3 ppmv, corresponding to $178.97 \mathrm{GtC}$ based on $2.123 \mathrm{GtC} / \mathrm{ppmv}$ (Joos et al. 2004)
}

${ }^{7}$ 25.8\% (124/480) of total emissions (274+156=430 GtC) (see House et al. 2002) 


\section{Carbon budget before 1850}

The carbon budget prior to 1850 is considerably less well known, especially regarding landuse estimates. The use of fossil fuel before 1850 was rather insignificant and estimated to a total of $1.25 \mathrm{GtC}$ (Marland et al. 2006). Deforestation on the other hand was already by 1850 substantial in temperate regions (Prentice et al. 2001), contributing to an accumulated humanrelated carbon release until 1850 of 48-57 GtC estimated by DeFries et al. (1999).

\subsection{Atmospheric $\mathrm{CO}_{2}$ concentration}

Direct measurements of atmospheric $\mathrm{CO}_{2}$ concentration has been performed since 1958 at Mauna Loa in Hawaii. Currently (2004), the yearly averaged $\mathrm{CO}_{2}$ level is 377 ppmv, with an annual increase of 1.9 ppmv, averaged from 1995 until 2004 (Keeling \& Whorf 2005). The present $\mathrm{CO}_{2}$ concentration corresponds to $800 \mathrm{GtC}$ with an approximate $4 \mathrm{GtC}$ annual increase based on the well-established conversion rate $2.123 \mathrm{GtC} / \mathrm{ppmv}^{\mathrm{CO}} \mathrm{C}_{2}$ (Joos et al. 2004). The pre-industrial $\mathrm{CO}_{2}$ level is commonly referred to as $280 \pm 10 \mathrm{ppmv}$ (Prentice et al. 2001), implying an atmospheric increase of approximately $200 \mathrm{GtC}$ since the start of the industrial revolution about 200 years ago. (Figure 5)

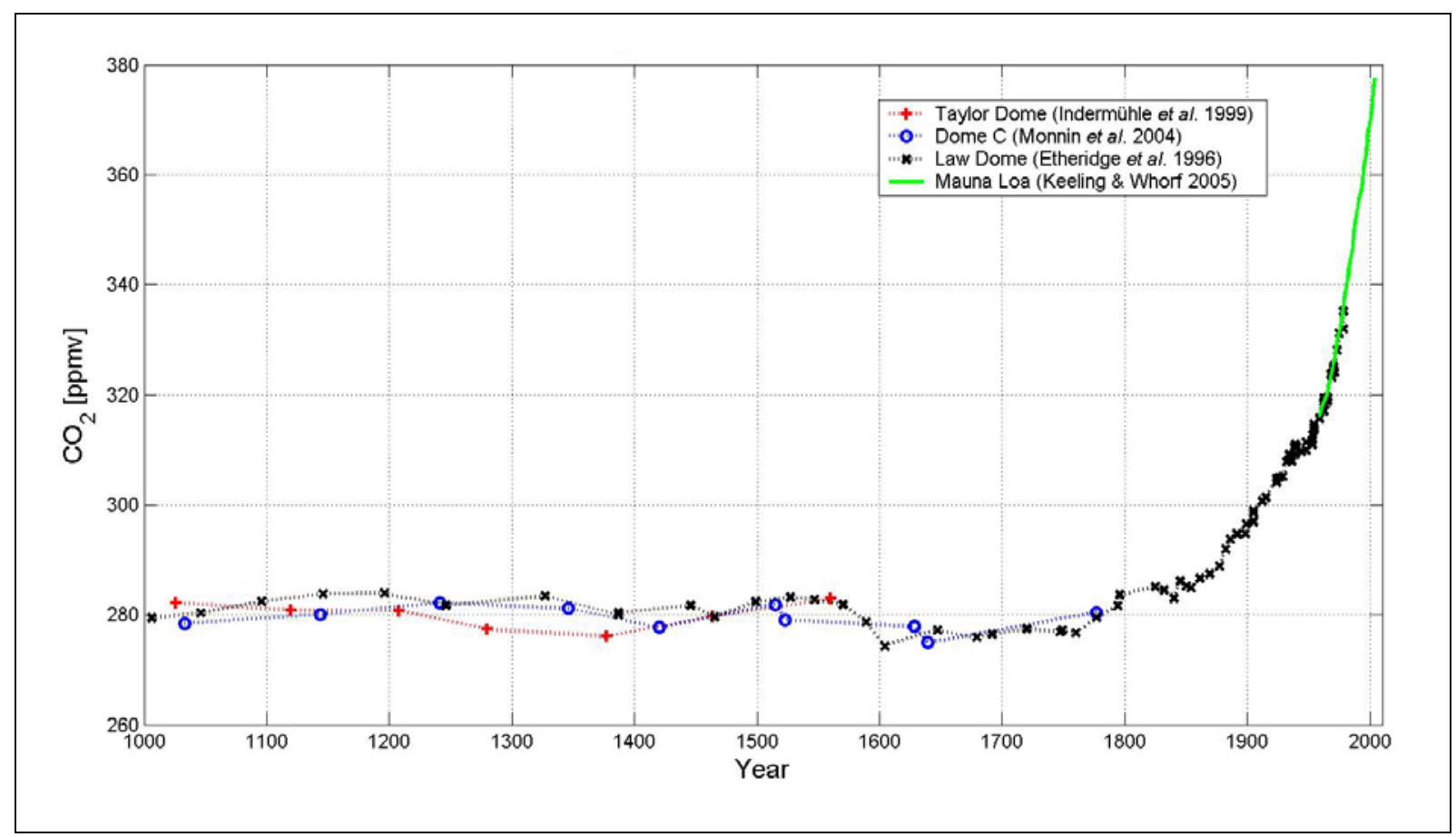

Figure 5. Atmospheric $\mathrm{CO}_{2}$ concentration during the last 1000 years, adapted from Indermühle et al. (1999), Monnin et al. (2004), Etheridge et al. (1996) and Keeling \& Whorf (2005). [ppmv]

For comparison, Köhler \& Fischer (2004) estimated global pre-industrial vegetation and soil carbon to 622-908 GtC and 1150-1700 GtC, respectively, while present-known fossil fuel reserves and resources are approximately 4000-5000 GtC (Sundquist 1993; Falkowski et al. 2000). However, estimates of historical and even present carbon stocks and changes in the global terrestrial ecosystem, especially for the tropical forests, are all associated with large uncertainties, as further discussed in Houghton (2003b; 2005b) and House et al. (2003). 


\subsubsection{Past atmospheric $\mathrm{CO}_{2}$ concentration}

Extracted ice cores with enclosed air bubbles from accumulated snow provide excellent opportunities for direct studies of past atmospheric composition (Petit et al. 1999; Wolff 2005). Ice cores from Antarctica with a slow accumulation rate provide the longest time records, though precise time resolution is limited to about 200 to 550 years (Monnin et al. 2001). Faster accumulating ice from Greenland (Andersen et al. 2004) provides higher temporal resolution but lacks the extensive time records of the Antarctica. Ice cores from other glacial regions such as the Andes, the Himalayas and Kilimanjaro (Thompson et al. 2003) provide additional direct recordings of past greenhouse gas levels.

An alternative $\mathrm{CO}_{2}$ proxy is the stomatal frequency method, based on the fact that the atmospheric $\mathrm{CO}_{2}$ level determines the number of leaf cells developing into stomata (Woodward 1987), and the latter can be used to calculate a proxy for atmospheric $\mathrm{CO}_{2}$. Using this method, Rundgren et al. (2005) reconstructed atmospheric $\mathrm{CO}_{2}$ during the last interglacial from Danish lake sediments, with results showing agreement with ice core reconstructions but with a larger variability, probably as a result of a higher temporal resolution, about 100 years.

Analysis of the Vostok ice core in Antarctica by Petit et al. (1999) show a similar trend in atmospheric $\mathrm{CO}_{2}$ for all four glacial cycles in the last 420,000 years. A peak-level of 280-300 ppmv was found at the warm but short interglacial period followed by a slow decrease to values of 180-200 ppmv at the glacial maximum before a rapid increase to the higher level at a new interglacial. Each cycle is about 100,000 years, thus showing a variance on equal timescale as the eccentricity variation according to the Milankovitch theory. Ice core records covering the last 740,000 years and eight glacial cycles is now available (Augustin et al. 2004), and recently atmospheric $\mathrm{CO}_{2}$ concentrations back to 650,000 BP (Siegenthaler et al. 2005), the latter confirming the cyclic $\mathrm{CO}_{2}$ behaviour found by Petit et al. (1999). (Figure 6)



Figure 6. Atmospheric $\mathrm{CO}_{2}$ levels during the last 650,000 years, adapted from Siegenthaler et al. (2005) and Petit et al. (1999). [ppmv]

Indermühle et al. (1999) and Monnin et al. (2004) performed detailed ice core analysis from the Holocene (Figure 2). Observations from ice core records based on deuterium ${ }^{8}$

\footnotetext{
${ }^{8}$ Measurements of ice core deuterium are used to derive corresponding past temperatures (e.g., Petit et al. 1999)
} 
measurements indicate that $\mathrm{CO}_{2}$ changes usually lag behind temperature changes by between 800 and 1900 years (Siegenthaler et al. 2005). However, the causes for the glacial-interglacial $\mathrm{CO}_{2}$ variation are not yet completely understood (Archer et al. 2000; Sigman \& Boyle 2000).

\subsection{Human population}

Modern homo sapiens is believed to have originated in central Africa about 200,000 years ago, and spread first to the Middle East region followed by Asia and Europe, and then Australia 40,000 years ago (Simmons 1996; Roberts 1998). America was the last continent to be inhabited by human beings, starting with migration through the land connection over Bering Sound at the end of the latest glacial. By this time, 10,000 years ago, only about 4 million humans populated the entire planet (McEvedy \& Jones 1978).

Since the end of the latest glacial the world population has increased greatly, and is today estimated to exceed 6.5 billion people (U.S. Census Bureau 2006). For most of the Holocene, the population growth was rather modest and occasionally even negative as a result of major diseases or warfare (Ruddiman 2003). The development of the human population during the Holocene has been estimated by McEvedy \& Jones (1978), see Figure 7.



Figure 7. Global human population during the last 6000 years in logarithmic scale, derived from McEvedy \& Jones (1978). [million]

Thus, the human population at the beginning of the Holocene was rather limited. By this time, humans are thought to have been mainly hunters and gatherers, relying on what nature provided through fruits, nuts and hunted game (Simmons 1996). Being completely dependent on the surrounding environment for survival, populations are believed to have had to move their camps frequently in response to season and climate changes and hence did not establish any permanent settlements prior to the development of agriculture (Gupta 2004).

\subsection{Land-use}

Changed climatic conditions after the latest glacial brought higher temperatures, more precipitation and an increasing atmospheric $\mathrm{CO}_{2}$ level, which possibly initiated domestication of animals and plants in tropical and subtropical regions (Gupta 2004). Grazing animals such as goats and sheep were likely domesticated before agriculture commenced (Simmons 1996), contributing to the transformation from hunting to herding and later agricultural practice. 


\subsubsection{Origin of agriculture}

Agricultural practice is believed to have started 10,000 years ago in the Fertile Crescent around the Tigris and Euphrates rivers as well as along the Nile Valley in Egypt, from where it gradually spread into Europe, North Africa and western Asia (Roberts 1998). Early agriculture evolved independently in other regions, notably around the Yellow River in China, the Indus Valley in India, regions in Central America and in the Andes (Simmons 1996). Together with agricultural development the first permanent settlements and societal systems were established (Gupta 2004). Flood plains cleared of trees were used for intensive cultivation and pasture, which supported stable settlements for long periods (Williams 2000).

In Europe, human impact on forest vegetation by clearing, cultivation and grazing is believed to have been "significant for at least 6000 years" (Williams 2000), together with the establishment of the first permanent settlements. In Central and South America humaninduced forest fires were used for expanding agriculture during the middle Holocene by Maya and Inca cultures (Carcaillet et al. 2002), with a distinct decrease 500 years ago associated with the dramatic human population decline caused by the diseases following the first European contact. Major human transformation of the forests in eastern North America started only after the introduction of steel axes by the European settlers (Doolittle 2004). In China, anthropogenic disturbance by early agriculture and settlement is suggested to explain the observed forest pollen decline in the middle and lower Yangtze regions by 5000 years BP (Ren 2000; Ren \& Beug 2002).

\subsubsection{Fire}

Natural fires have always occurred, depending on climate, volcanic activity and vegetation (Carcaillet et al. 2002). Fire is essential in numerous plant communities, where tree, grass and shrub species have developed in response to frequent fires. Nutrients are rapidly mobilized by fire, encouraging establishment of early succession vegetation in newly burnt areas (Bonan 2002). In addition, biomass burning is important for atmospheric chemistry through release of trace gases and aerosols, as well as for the global carbon cycle (Thonicke et al. 2001).

Fire has often been used by man for clearing forested land, and is therefore seen as an indicator of early human activity in several charcoal records in Europe, America and Southeast Asia (Clark et al. 1989; Carcaillet et al. 2002). Increasing charcoal levels are often accompanied with decreasing tree pollen and increasing cereal and weed pollen, indicating human cultivation and domesticated grazing animals (Roberts 1998; Williams 2000). In addition to agriculture, fire has commonly been used to open up forestland for pasture, after which browsing sheep and goats often prevent natural tree regeneration (Ruddiman 2003). Furthermore, the development of seemingly "natural" ecosystems such as the African savannas, the Brazilian cerrado, several Mediterranean-type ecosystems and prairie grasslands are all believed to have evolved as a result of human burning activities (Thonicke et al. 2001).

\subsubsection{Non-permanent agriculture}

When nutrient conditions are too poor for permanent agriculture, an alternative farming method is shifting cultivation or "slash-and-burn", characterized by a cycle of regular alternating short farming and longer fallow periods (Metzger 2003). Initially forested land is cleared by man aided by fire, enriching the soil with nutrients from the ashes (Giardina et al. 2000). The cleared land is usually cultivated for 2-3 years before the nutrient level becomes too low to give an acceptable return (Crutzen \& Andreae 1990). The land is abandoned, allowing re-growth of secondary vegetation, typically for a 10-20 year fallow period before 
returning to re-clear and re-cultivate the initial plot (Brady 1996). A farmer typically has several plots at different stages in the shifting cultivation cycle.

According to Carcaillet et al. (2002), the increased biomass burning in Europe since 6000 years ago are best explained by agricultural development, probably at least initially applying a slash-and-burn agricultural system as suggested by Clark et al. (1989) and Ruddiman (2003), indicating that non-permanent agriculture might have been in use for thousands of years. Farming communities have practised traditional small-scale and sustainable slash-and-burn agriculture with long fallow periods and large areas of undisturbed forests (Tinker et al. 1996). Because of an increased population pressure, fallow periods in general have shortened significantly and are currently often too short for the land to recover its previous productivity between farming periods (Crutzen \& Andreae 1990). Current shifting cultivation practises therefore often result in reduced harvests, soil degradation, aerosol release as well as a net emission of carbon (Fearnside 2000).

\subsubsection{Land requirements for agricultural purposes}

By 1700 the global permanent cropland area was 266 million ha $^{9}$, as estimated by Klein Goldewijk (2001), and the world population 610 million according to McEvedy \& Jones (1978), which gives an average of 0.44 ha cropland per capita while an area twice this size was used for pasture. Corresponding values for 1990 are 0.28 ha cropland per capita and 0.65 ha pasture per person (Klein Goldewijk 2001), indicating an increased crop return per unit area as a result of increased efficiency in agricultural practices.

The size of land area per person for non-permanent agriculture is more uncertain and varies according to soil fertility, population density and length of the fallow season (Grigg 1974). Grigg (1974) estimated average land area with crops in modern shifting cultivation at 0.44 ha per person in Africa while in India, South East Asia and southern China the corresponding area was 0.28 ha per person, though by including fallow areas the total land requirement was higher, in Asia 2 ha per person. A more recent estimate by Lanly (1985) based on current global shifting cultivation practices in the tropics by about 500 million people, gave an average of 0.17 ha under active cultivation per person, while the total land requirement including fallow areas was about 1 ha per person (see also Brady 1996).

Other food and nutrient sources for the human population are obviously possible, such as fishing and hunting. However, these sources were not included in the estimates of land requirements, neither was human-managed forestry and related potential carbon release taken into account in the present study, being focused only on agricultural land-use.

\subsubsection{Reforestation}

Forests have a remarkable power to regenerate and re-expand once human pressure declines, which is seen since the last century in parts of North America and Europe as marginal agriculture land has been abandoned as a result of intensified farming on more productive soils (Bonan 2002; Malhi et al. 2002). Plague and warfare are other powerful factors resulting in reduced land pressure and advancement of reforested areas (Ruddiman 2003), for instance during the Black Death (van Hoof et al. 2006) and major European conflicts as well as when new pathogens were introduced in America by the first European contact (Williams 2000).

\footnotetext{
${ }^{9} 1 \mathrm{ha}=0.01 \mathrm{~km}^{2}\left(1 \mathrm{~km}^{2}=100 \mathrm{ha}\right)$
} 


\subsection{Consequences of land-use}

As forest ecosystems contain a large proportion of the biospheric carbon in living biomass and soil organic matter, a major change in forest cover results in modifications of the global carbon cycle (Houghton \& Goodale 2004), making accumulated land-use change the second most important source of atmospheric carbon after fossil fuel use (Prentice et al. 2001). Apart from reducing vegetation carbon, $25-30 \%$ of the soil carbon in the upper meter of soil is released when clearing forests for permanent cultivation, as less crop production accumulates as litter and decomposes to soil compared to the higher forest litter fall (Guo \& Gifford 2002; Houghton \& Goodale 2004).

When fallow periods in slash-and-burn systems are short, as is currently the case in large parts of the tropics where population pressure is increasing (Crutzen \& Andreae 1990), shifting cultivation also results in a net soil carbon source, as less forest litter fall between the farming periods have time to be decomposed to soil (Fearnside 2000). For these reasons, widespread use of fire for land opening throughout the second part of the Holocene might explain the development of the observed atmospheric $\mathrm{CO}_{2}$ concentration during this period (Carcaillet et al. 2002). Ruddiman (2003) went further in linking early human land-use to a strong modification of the atmosphere and climate far prior to any large-scale fossil fuel burning (Section 1.1).

Deforestation followed by agriculture also causes aerosol releases that affects the atmospheric composition, increases soil erosion and causes a loss of soil organic matter (Tinker et al. 1996). Additional consequences are changes in water infiltration and the hydrological cycle (Tinker et al. 1996), as well as an increased eutrophication of rivers and lakes from the currently extensive use of fertilizers (Matson et al. 1997). By opening up the forest canopy, early succession species such as fir, birch and spruce flourish in human-influenced landscapes, while later succession species with a later maturity age, such as elm and oak, decline (Williams 2000; Bonan 2002). A fragmented mosaic of natural ecosystems in agriculture-dominated landscapes affects functions and composition for the remaining natural flora and fauna negatively (Saunders et al. 1991), and results in a decreased biodiversity (Pimm \& Raven 2000). 


\section{MATERIAL AND Methods}

\subsection{The Lund-Potsdam-Jena Dynamic Global Vegetation Model}

The Lund-Potsdam-Jena Dynamic Global Vegetation Model (LPJ-DGVM) is a coupled biogeography-biogeochemistry model, which incorporates process-based representations of terrestrial vegetation dynamics and biogeochemical cycling. The model, developed in Microsoft Visual $\mathrm{C}++^{+}$, has become a so-called community model and is being used by a large number of scientists. LPJ-DGVM has previously been shown to, e.g., successfully reproduce the interannual global exchange of $\mathrm{CO}_{2}$ with the atmosphere (Sitch et al. 2003), global patterns of vegetation distribution (Sitch et al. 2003; Hickler et al. 2006), Holocene terrestrial carbon development (Kaplan et al. 2002), and the observed high-latitude vegetation greening trend in the 1980s' and 1990s' (Lucht et al. 2002).

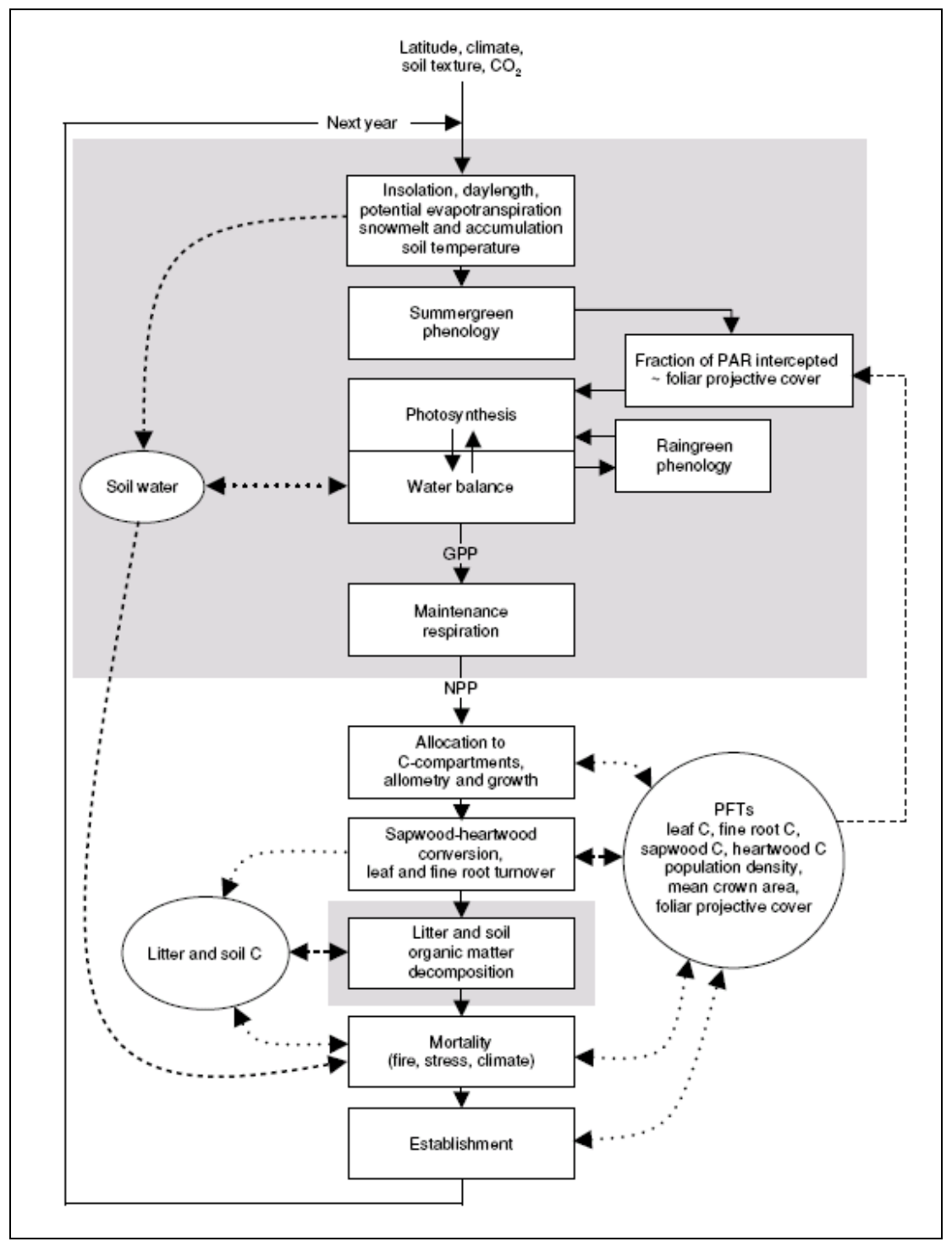

Figure 8. Structure of LPJ-DGVM represented as a flow chart for one simulation year. Modules with shaded background are called on a daily time step basis while the other modules are called annually. (From Sitch et al. 2003) 
The structure of LPJ-DGVM is based on modules, each mechanistically representing a welldefined set of ecosystem processes, linked together by a central framework (Figure 8). Ecophysiological processes, such as photosynthesis, soil water dynamics, stomatal regulation, and exchanges of carbon and water between soil, vegetation and the atmosphere are implemented on a daily time step basis. Changes in vegetation structure through growth, population dynamics and fire-disturbance are performed at the end of each simulation year. Leaf fall and dead biomass from mortality and root turnover are on a yearly basis added to the litter pool, which is divided into a highly labile fraction respiring directly into the atmosphere and two soil carbon pools with turnover times of 33 and 1000 years, respectively. The soil decomposition rate depends on the seasonal temperature and soil moisture.

Vegetation in each simulated grid cell is described as the fractional coverage of a set of plant functional types (PFTs), broadly accounting for the diversity in plant structure and function (Bonan 2002). In LPJ-DGVM, global vegetation is commonly represented by 10 PFTs, differentiated by bioclimatic limits, and physiological, morphological and life history characteristics, which govern competition for resources (Sitch et al. 2003). For computational reasons, the PFT specifically representing Siberian larch (Larix sibirica) was excluded, while the other 9 standard PFTs were implemented as in Sitch et al. (2003).

LPJ-DGVM is driven by monthly data on climate (temperature, precipitation and solar insolation), atmospheric $\mathrm{CO}_{2}$ concentration and soil texture. The computational modelling process over the entire simulation time is performed for one grid cell at the time, and thus not taken into account the vegetation development in neighbouring grid cells. In this study the model version described in Sitch et al. (2003), with updated hydrological processes by Gerten et al. (2004), the fire module explained in Thonicke et al. (2001), and minor parameter updates given in Hickler et al. (2006; supplementary material S2) was used.

\subsection{Incorporating human land-use within LPJ-DGVM}

Two modes of agriculture were implemented within the model:

- Permanent agriculture was implemented by forest clearance, followed by natural vegetation without allowing tree establishment. The cleared forest biomass was added to the litter pool for decomposition. Without trees, the vegetation in the model is composed of two herbaceous PFTs (with C3 or C4 photosynthesis, see Sitch et al. 2003). These PFTs share fundamental physiological and growth characteristics with crops (Bondeau et al. 2006).

- Non-permanent agriculture was implemented as a rotating scheme between humans setting fire to the natural vegetation, facilitating productive agriculture for a few years (farming time) followed by a longer fallow period when tree establishment and growth was permitted. After the fallow period, another agriculture cycle was started by fire.

Harvest was not explicitly implemented. Instead, when operated in agricultural mode, $80 \%$ of the grass litter was respired directly into the atmosphere compared to $70 \%$ for the standard set-up, implicitly realising harvest. This resulted in a lower addition of litter to the carbon pools than without agriculture, and thus contributed to a decrease in the soil carbon pools.

The land-use data set was divided into seven time-slices to cover the simulation period from 6000 BP until present (1998) (Table 2). During each time-slice, the land-use mode in an 
individual grid-cell was kept constant, though the land-use mode could change between timeslices. The spatial extent of the two modes of agriculture through time is shown in Figure 14.

Table 2. Time-slices and population data [millions] used to construct the land-use data set. Population data for 1990 from Klein Goldewijk (2001), other years from McEvedy \& Jones (1978).

\begin{tabular}{lcccc}
\hline Time-slice & First year & Last year & Years & Population \\
\hline a) $6000 \mathrm{BP}$ & 6000 BP & 5001 BP & 1000 & 7 \\
b) 4000 BP & 5000 BP & 3001 BP & 2000 & 27 \\
c) 2000 BP & 3000 BP & AD 499 & 1500 & 170 \\
d) AD 1000 & AD 500 & AD 1499 & 1000 & 265 \\
e) AD 1700 & AD 1500 & AD 1774 & 275 & 610 \\
f) AD 1850 & AD 1775 & AD 1920 & 145 & 1200 \\
g) AD 1990 & AD 1921 & AD 1998 & 78 & 5300 \\
\hline
\end{tabular}

One example of a simulated development of the three carbon pools (vegetation, soil and litter) is shown in Figure 9, with applied climatic data from the grid cell corresponding to the area including and surrounding Lund in southern Sweden. Non-permanent agriculture with shorter and shorter fallow periods (Section 3.3.2) for each time-slice was applied during the four first time-slices of the simulation period, and followed by permanent agriculture during the last three time-slices (Section 3.3.1).

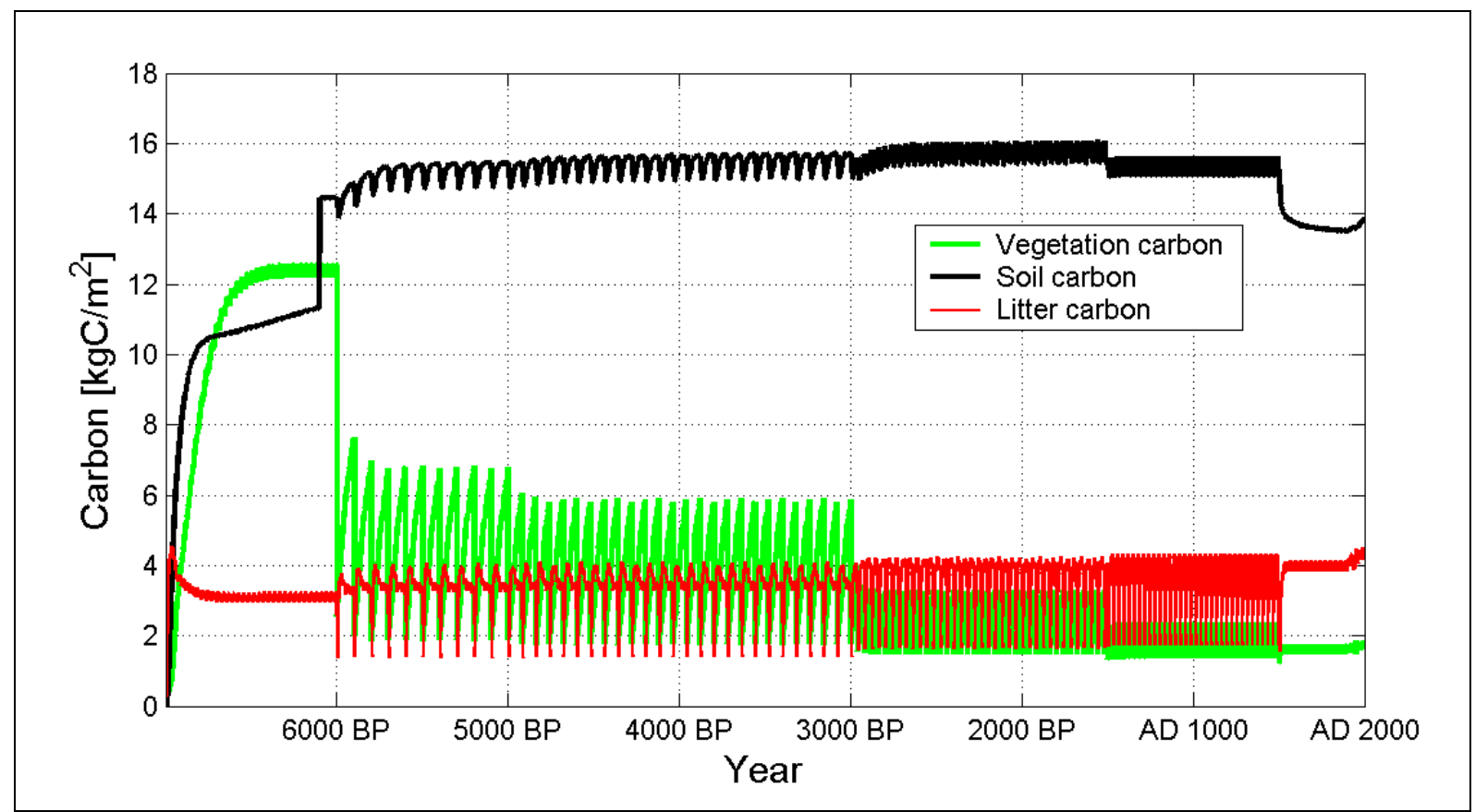

Figure 9. Example of the simulated development of the three carbon pools, with applied climatic data from the grid cell corresponding to the area including Lund in southern Sweden. The model was spun up for 1000 years, until $6000 \mathrm{BP}$, to allow the carbon pools to reach equilibrium status with the long-term climate (Section 3.4). Non-permanent agriculture was in the this example applied during the first four time-slices, until AD 1499, with shorter fallow periods for each time-period (Section 3.3.2), resulting in lower maximum vegetation the shorter the fallow period. Permanent agriculture was applied during the last three time-periods, AD 1500 until AD 1998 (Section 3.3.1). The increase in terrestrial carbon pools during the very last century was a result of changes in applied climate and atmospheric carbon dioxide concentration during this century (Section 3.4). 


\subsection{Land-use data set}

A gridded global data set at $0.5^{\circ}$ x $0.5^{\circ}$ resolution (59,191 non-glacial-covered land cells), with seven time-slices of human civilization and land-use development during the last 6000 years (Table 2) was derived from the literature (e.g., Sherratt 1980; Turner et al. 1990; Simmons 1996; Roberts 1998). The first four time-slices were based on maps from Lewthwaite \& Sherratt (1980), representing the spread of human civilization by: (a) 6000 BP, (b) $4000 \mathrm{BP}$, (c) $2000 \mathrm{BP}$ and (d) AD 1000. The four maps were manually digitised with ArcView and IDRISI to facilitate further computer-based processing (Figure 10).

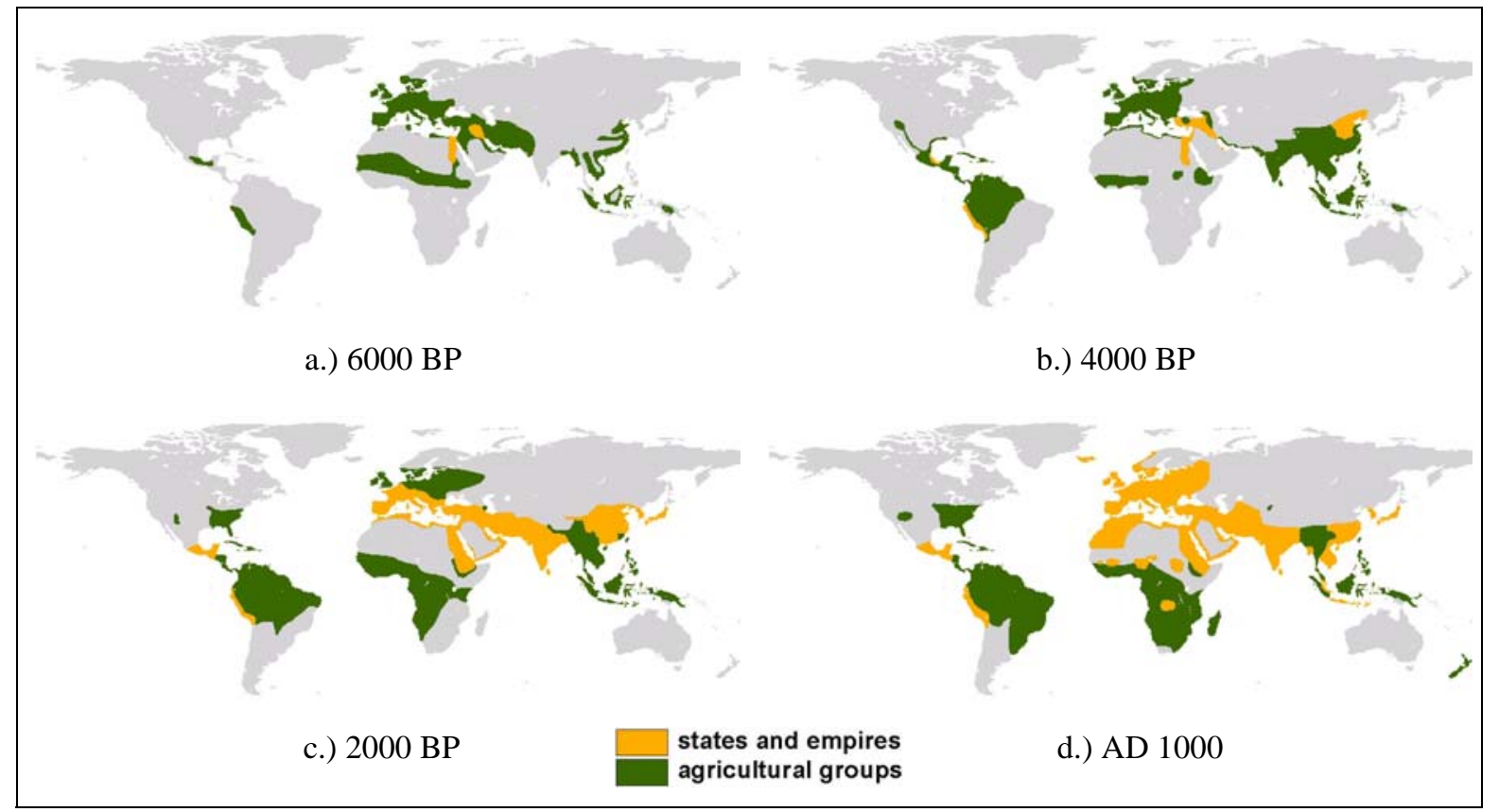

Figure 10. Development of civilization represented as "states and empires” and "agricultural groups", adapted from Lewthwaite \& Sherratt (1980).

The 2000 BP map from Lewthwaite \& Sherratt (1980) has been adapted by Roberts (1998) with the two civilisation levels now categorised as "complex stratified agriculture" and "simple peasant agriculture", respectively. This interpretation of the same map was lately further developed in the hypothesis raised by Ruddiman (2003; 2005b).

An additional series of three time-slices were taken from the digital HYDE database ${ }^{10}$ (Klein Goldewijk 2001): (e) AD 1700, (f) AD 1850 and (g) AD 1990 (Figure 11; Section 1.2).

\footnotetext{
${ }^{10}$ The History Database of the Global Environment is available through http://www.mnp.nl/hyde/ (2006-06-13)
} 


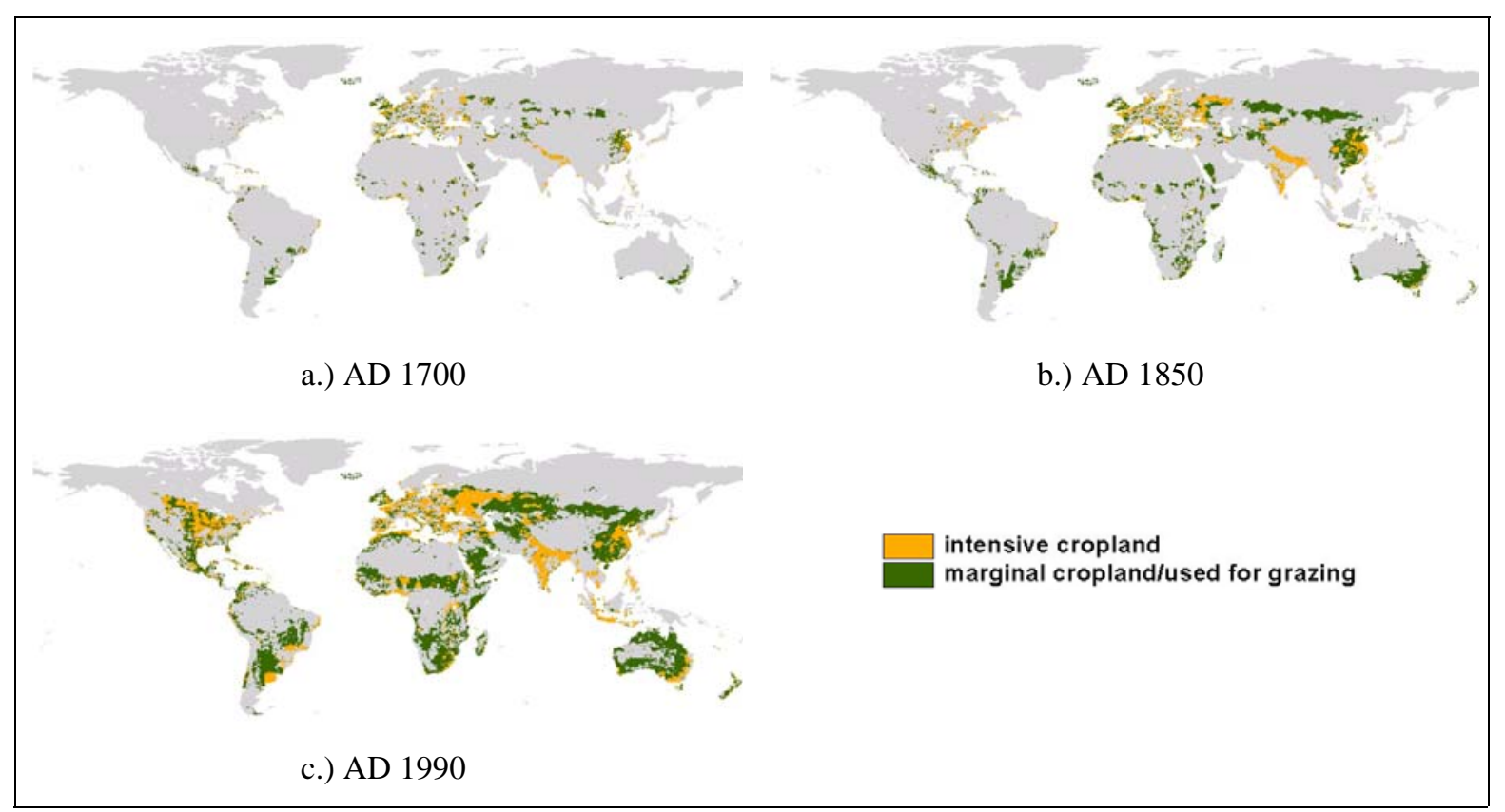

Figure 11. Agriculture represented as “intensive cropland” and "marginal cropland/used for grazing”, adapted from the HYDE database (Klein Goldewijk 2001).

\subsubsection{Permanent agriculture}

For the last three time-slices (1500-1998), the spatial distribution of areas assigned permanent agriculture was taken as the land-use classes "intensive cropland" and "marginal cropland/used for grazing" in the HYDE database (Figure 11). Before 1500, only areas referred to as "states and empires" in Lewthwaite \& Sherratt (1980) (Figure 10) were assumed to be possibly covered by permanent agriculture (following Roberts 1998 and Ruddiman 2003), whereby grid cells assigned permanent agriculture during time-slice (e) were used to constrain the maximum extent of permanent agriculture during the four preceding time-slices (a-d); except Egypt and the Fertile Crescent, for which the extent of farmland was taken from the individual time-slices.

Permanent agriculture has been a prerequisite for the development of state- or empire-like societies (Diamond 1997), which explains why the spread of complex societies has been strongly associated with the spread of permanent agriculture (Roberts 1998). Furthermore, $10 \%$ of each grid cell was considered inappropriate for agriculture and therefore left for natural vegetation (Ruddiman 2003), accounting for landscape heterogeneity, i.e., that some areas are always covered by ridges, streams etc, and therefore not suitable for agricultural use.

\subsubsection{Non-permanent agriculture}

For the earliest four time slices (a-d), "suitable" areas (see below) within the categories "states and empires" and "agricultural groups" from Lewthwaite \& Sherratt (1980) that were not already assigned permanent agriculture (see above) were assumed to be under non-permanent agriculture (Figure 10). For the three last time-slices (e-g), non-permanent agriculture was assumed to occur in all suitable areas on the globe not assigned by permanent agriculture.

Suitable areas were distinguished from unsuitable land as follows: only grid cells with a maximum elevation of 1000 meters were considered for farming in order to exclude less accessible forested areas (Ruddiman 2003). And just as for permanent agriculture, $10 \%$ of 
each grid cell was left for natural vegetation. Areas with limited potential natural vegetation, set to less than $2 \mathrm{kgC} / \mathrm{m}^{2}$, were regarded as unproductive and therefore excluded from nonpermanent agriculture. Regions with sparse populations of less than 5 inhabitants $/ \mathrm{km}^{2}$ in 1700, the earliest HYDE data available, were regarded as unsuitable areas for non-permanent agriculture during the four earliest time-slices (a-d). Furthermore, densely populated regions with more than 25 inhabitants $/ \mathrm{km}^{2}$, as well as sparsely populated areas as defined above, based on HYDE for respective time-slice, were regarded inappropriate for non-permanent agriculture during the three last respective time-slices (e-g). In addition, for the last time-slice (g) non-permanent agriculture was restricted to areas south of latitude $25^{\circ} \mathrm{N}$. (Figure 12)

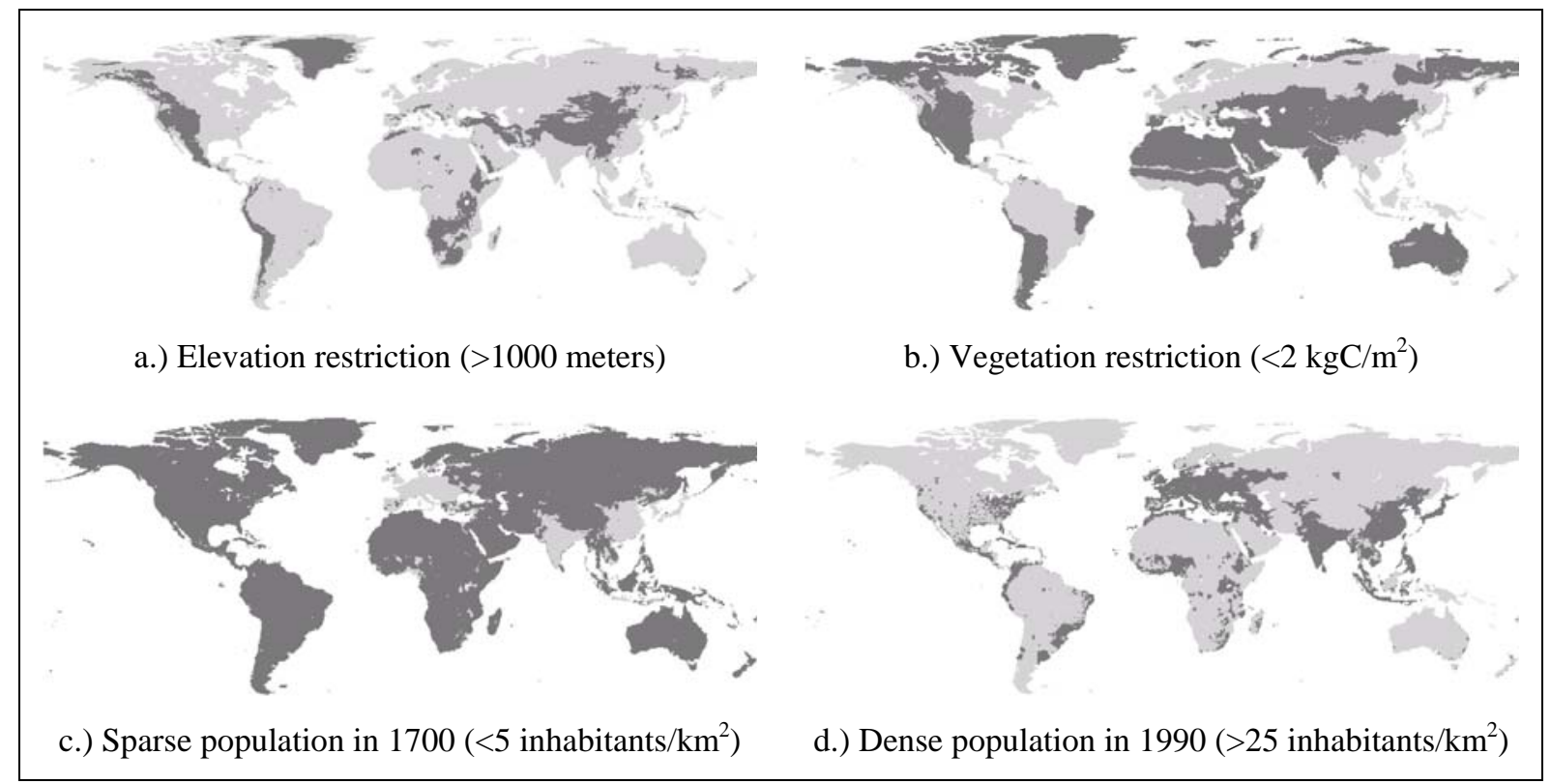

Figure 12. Examples of applied restrictions for developing suitable areas for non-permanent agriculture (unsuitable areas marked with dark colour).

The farming period $t_{\text {farm }}$ was set to 4 years (Lanly 1985). The required farming area under crops per person $a_{\text {person }}$ was set to $1 / 6$ ha ([Lanly 1985]; based on current global nonpermanent farming practices, mainly in the tropics) and to $4 / 6$ ha for the first two time-slices, when non-permanent farming was more widespread in less favourable climatic zones. $a_{\text {person }}$ and data on global population $p_{\text {global }}$ (McEvedy \& Jones 1978; Klein Goldewijk 2001; Table 2 ) were used to derive the fallow period $t_{\text {fallow }}$ (average period between the end of a farming period and the start of the next farming period):

$$
t_{\text {fallow }} \approx \frac{a_{\text {suit }}}{p_{\text {global }} * f_{\text {non_perm }} * a_{\text {person }} * \frac{1}{t_{\text {farm }}}}
$$

For this purpose, the fraction of the global population depending on non-permanent agriculture $f_{\text {non_perm }}$ had to be estimated (Table 3 ). By multiplying $p_{\text {global }}$ with $f_{\text {non_perm }}$ and $a_{\text {person, }}$, the area required for farming at a given time was derived. Together with numbers of the areas categorized as suitable for non-permanent agriculture $a_{\text {suit }}$ (see above), the farming area requirement was used to calibrate an approximate global average fallow period for each time-slice (Equation 1; Table 3). 
Table 3. Numbers used for calibrating an approximate global average fallow period $t_{\text {fallow }}$ [years] for non-permanent agriculture during respective time-slice. Suitable areas for non-permanent agriculture $a_{\text {suit }}$ [million $\mathrm{km}^{2}$ ] derived according to Section 3.3.2. Global population data $p_{\text {global }}$ [million] from Table 2. Estimated fraction of the world population living from non-permanent agriculture $f_{\text {non-perm }}$ for time-slice (c) based on Ruddiman (2005b), for time-slice (g) based on Lanly (1985), while fractions for the other time-slices are best estimates. Required farming area under crops per person $a_{\text {person }}$ [ $\mathrm{km}^{2} /$ person] for time-slices (c-f) based on Lanly (1985) while a four times larger area for time-slices (a-b) were assumed because of less developed cultivation techniques and that these agricultural areas were situated in less favourable climatic zones. Farming period $t_{\text {farm }}$ based on Lanly (1985).

\begin{tabular}{lcccccc}
\hline Time-slice & $\boldsymbol{a}_{\text {suit }}$ & $\boldsymbol{p}_{\text {global }}$ & $\boldsymbol{f}_{\text {non_perm }}$ & $\boldsymbol{a}_{\text {person }}$ & $\boldsymbol{t}_{\text {farm }}$ & Applied $_{\text {fallow }}$ \\
\hline a) & 4.07 & 7 & 0.75 & 0.0067 & 4 & 246 \\
b) & 5.72 & 27 & 0.50 & 0.0067 & 4 & 196 \\
c) & 5.53 & 170 & 0.25 & 0.0017 & 4 & 146 \\
d) & 4.86 & 265 & 0.22 & 0.0017 & 4 & 96 \\
e) & 2.93 & 610 & 0.20 & 0.0017 & 4 & 76 \\
f) & 5.65 & 1200 & 0.15 & 0.0017 & 4 & 56 \\
g) & 5.40 & 5300 & 0.11 & 0.0017 & 4 & 26 \\
\hline
\end{tabular}

\subsubsection{The developed land-use data set}

The land-use data set with permanent and non-permanent agriculture for the seven time-slices was derived following the procedure explained above, coarsely representing the development of human civilization and land-use expansion in order to facilitate a first estimate of changes in anthropogenic land-use-related carbon fluxes during the last 6000 years. The development over time of land areas assigned with the two modes of agriculture following this procedure is shown in numbers in Figure 13, and spatially in Figure 14. Detailed data of the assigned agricultural land areas per continent for each time-slice is given in Appendix A.

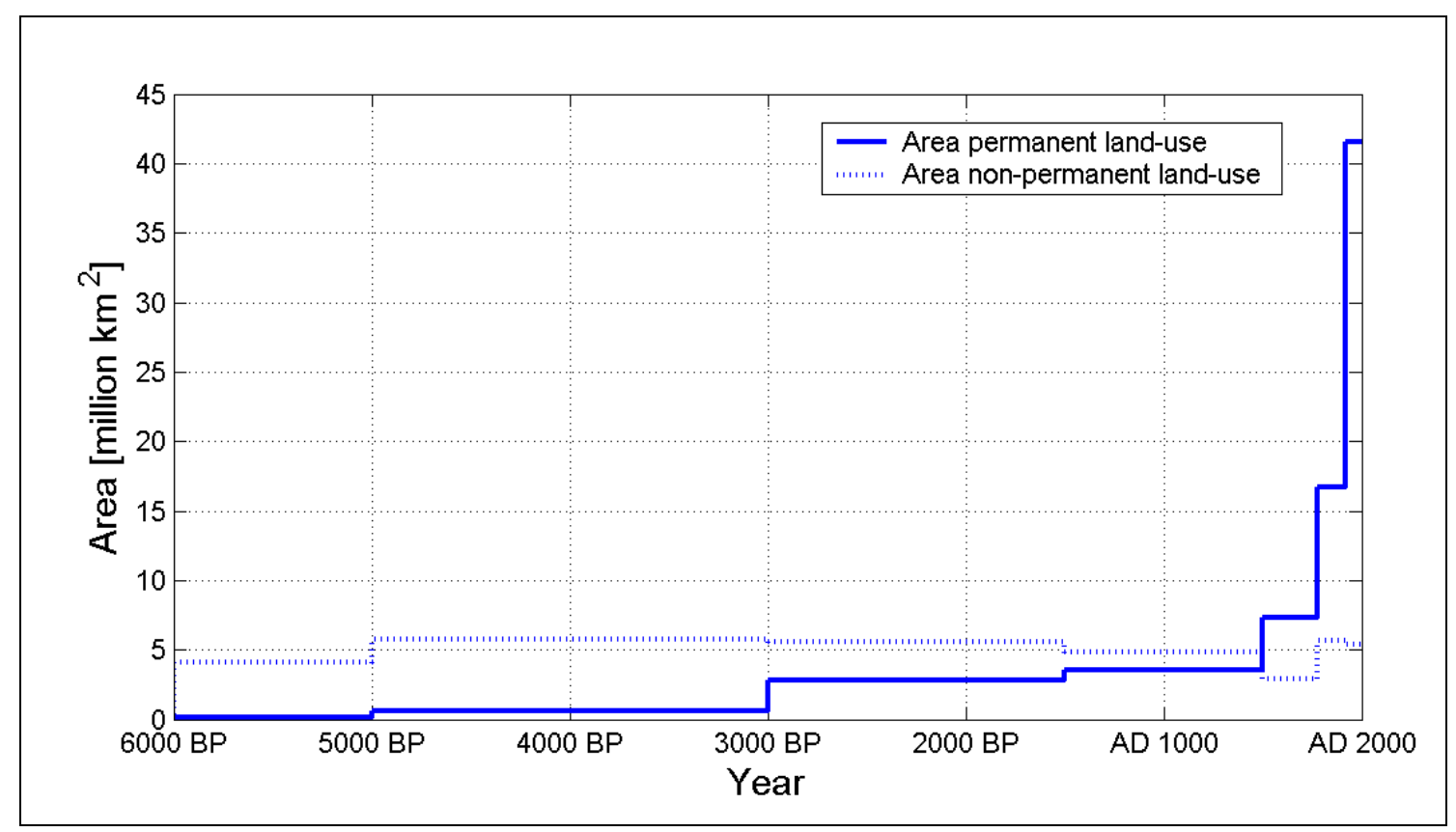

Figure 13. The development of the global land areas assigned with the two modes of agriculture with time for this simulation study. In comparison the Earth's total land area is estimated to 134 million $\mathrm{km}^{2}$ (Klein Goldewijk 2001). 


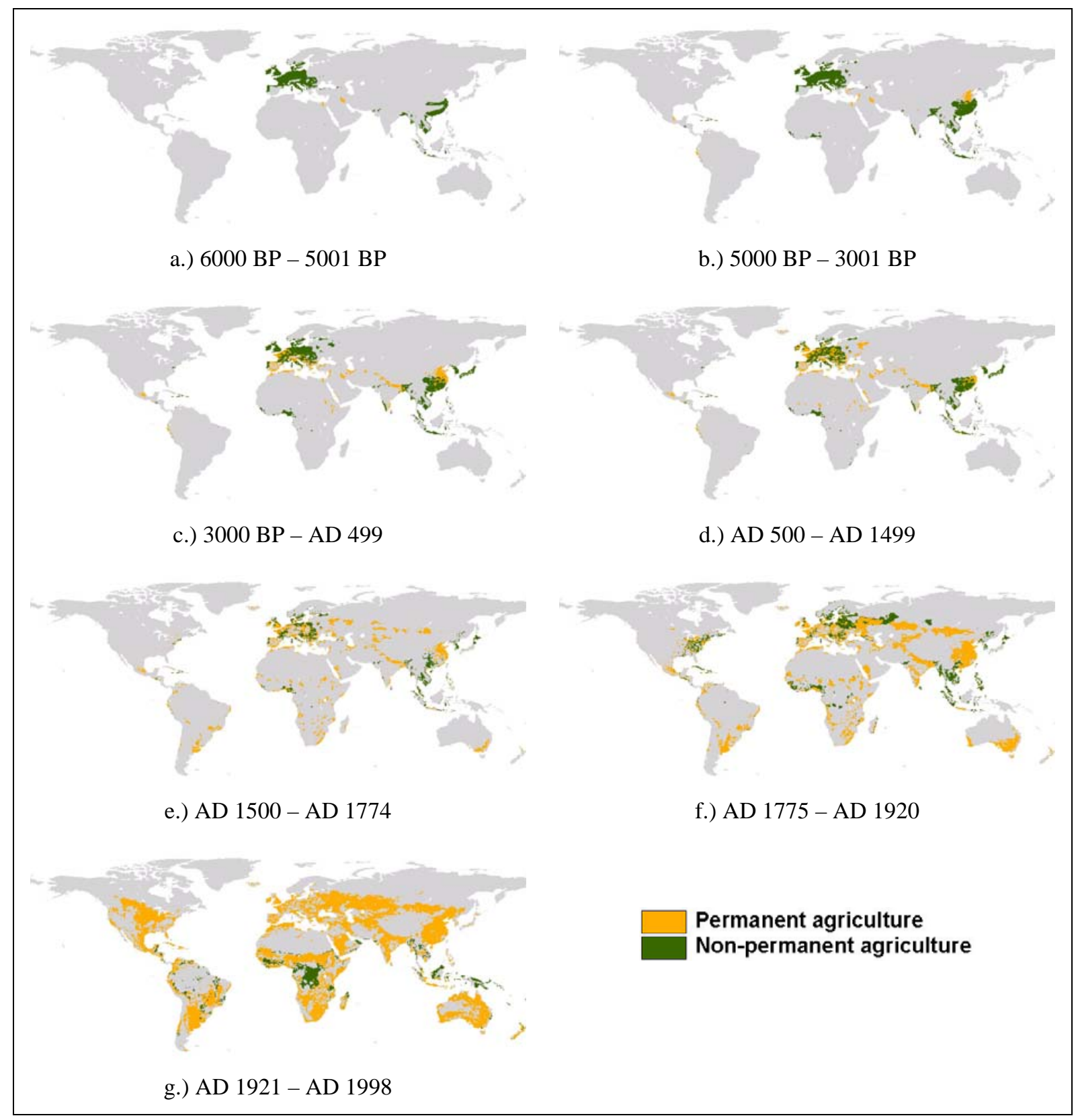

Figure 14. The developed land-use data set with spatial extent of areas assigned permanent and nonpermanent agriculture during seven time-slices (6000 BP until AD 1998).

\subsection{Modelling protocol}

Monthly mean surface climate data of temperature, precipitation and percentage sunshine hours were taken from the CRU05 (1901-1998) data set on a $0.5^{\circ}$ x $0.5^{\circ}$ global land grid provided courtesy by the Climate Research Unit (CRU), University of East Anglia (New et al. 1999; 2000). Land elevation data was taken from New et al. (1999), shown in Figure 15. 


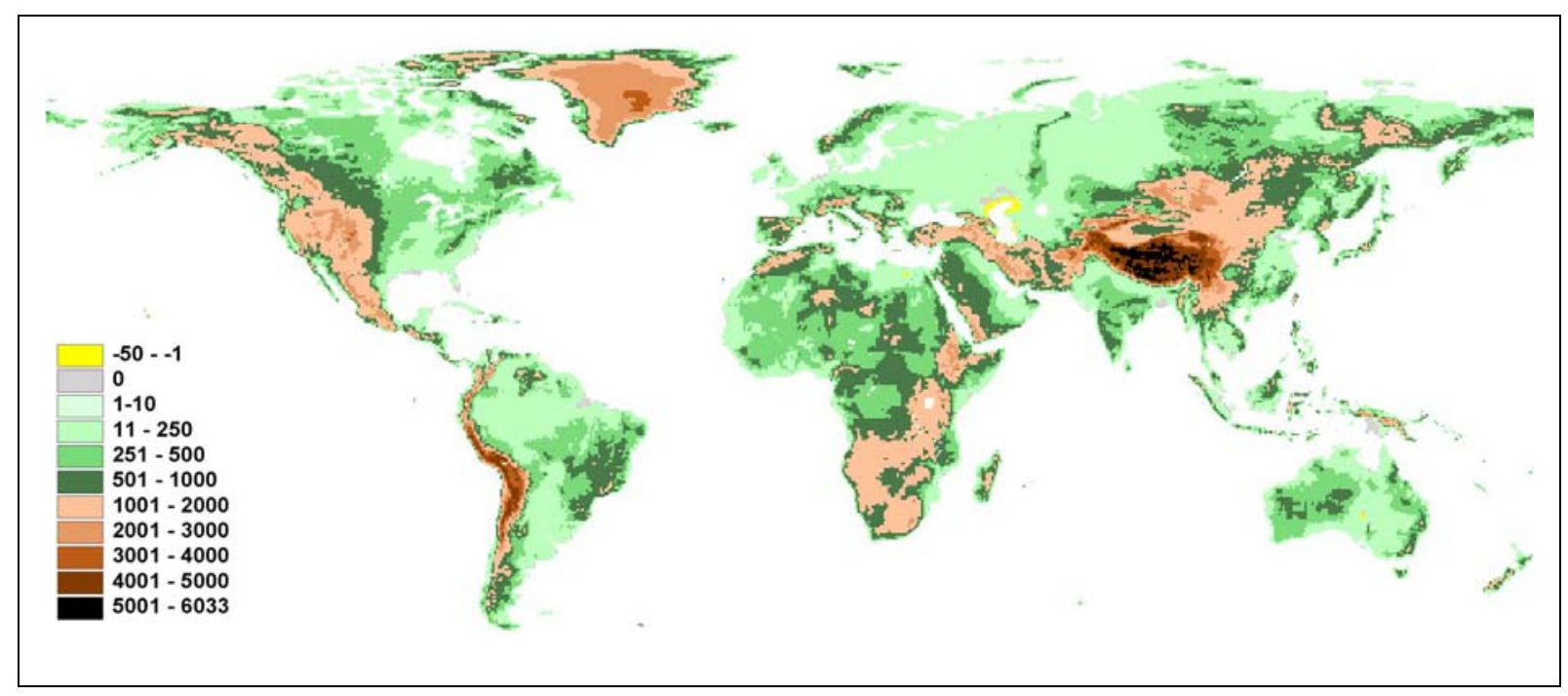

Figure 15. Elevation for all land grid cells except Antarctica, derived from New et al. (1999). [m]

The atmospheric $\mathrm{CO}_{2}$ concentration was held constant at 275 ppmv, which is approximately the average level for the 6000 years before the industrial revolution based on ice core data from Indermühle et al. (1999) and Monnin et al. (2004), see Appendix B for details. For the last 98 years (1901-1998), historical annual mean $\mathrm{CO}_{2}$ values from the Carbon Cycle Model Linkage Project (McGuire et al. 2001) were applied. Soil texture data were as in Sitch et al. (2003), based on the FAO soil data set (Zobler 1986; FAO 1991).

The simulation process started from bare ground, and the model was spun up for 1000 years to allow vegetation, soil and litter carbon pools to reach equilibrium status with the long-term climate. During the spin-up detrended climate data from the first 30 years (1901-1930) of the CRU05 climate data set, was used repetitively to get an inter-annually varying climate to receive a variation in dryness/wetness, which is required by the fire module for a realistic vegetation representation (Thonicke et al. 2001). The same 30 years of climate data was further used during the entire simulation period, except for the period 1901 until 1998, when historical CRU05 and $\mathrm{CO}_{2}$ data were used. See also Figure 9 for one simulation example.

In one run the model was used to simulate potential natural vegetation and carbon pools; and in the second run the model was run with the developed land-use data set. The difference between the simulated carbon pools in both runs was taken as an estimate of the carbon emissions caused by land-use. This approach neglects climate variations during the study period, except for the last 98 years. These variations did, however, not play a considerable role for the global carbon cycle during the last 6000 years (Joos et al. 2004).

The computational modelling procedure was set up on a networked PC-cluster running with the Linux operating system (OS). With 8 high-performance computers operating in parallel mode on the cluster, one global simulation with the land-use data set took about 10 hours to execute. In comparison, the same simulation set up on a single PC with Windows OS was estimated to take at least 1,200 hours, equivalent to more than 7 weeks, figures emphasising the computational difficulties to model thousands of simulation years on a global scale. 



\section{RESULTS}

The simulated potential natural, pre-industrial vegetation carbon stock, $744 \mathrm{GtC}$, was in the middle of the "most realistic range" of 622-908 GtC from the global studies reviewed in Köhler \& Fischer (2004). Simulated soil carbon and the total terrestrial carbon stock for preindustrial times were also within the ranges in Köhler \& Fischer (2004). (Table 4)

Table 4. Simulated potential natural vegetation separated by carbon pool and total terrestrial carbon (vegetation + soil + litter), compared with a few other studies. [GtC]

\begin{tabular}{lrrrr}
\hline Study & $\mathbf{C}_{\text {Vegetation }}$ & \multicolumn{1}{c}{$\mathbf{C}_{\text {Soil }}$} & $\mathbf{C}_{\text {Litter }}$ & C $_{\text {Terrestrial }}$ \\
\hline Prentice et al. (2001) & $466-654$ & $1567-2011$ & $\mathrm{x}^{1}$ & $2221-2477$ \\
Sitch et al. (2003) & 923 & 1670 & 171 & 2764 \\
Köhler \& Fischer (2004) & $622-908$ & $1150-1700$ & $\mathrm{x}^{\mathbf{1}}$ & $1911-2422$ \\
This study [275 ppmv] & 744 & 1283 & 283 & 2311 \\
\hline
\end{tabular}

${ }^{1}$ Note that neither Prentice et al. (2001) nor Köhler \& Fischer (2004) separate the labile litter pool

Geographic allocation of potential natural vegetation and soil carbon are shown in Figure 16.

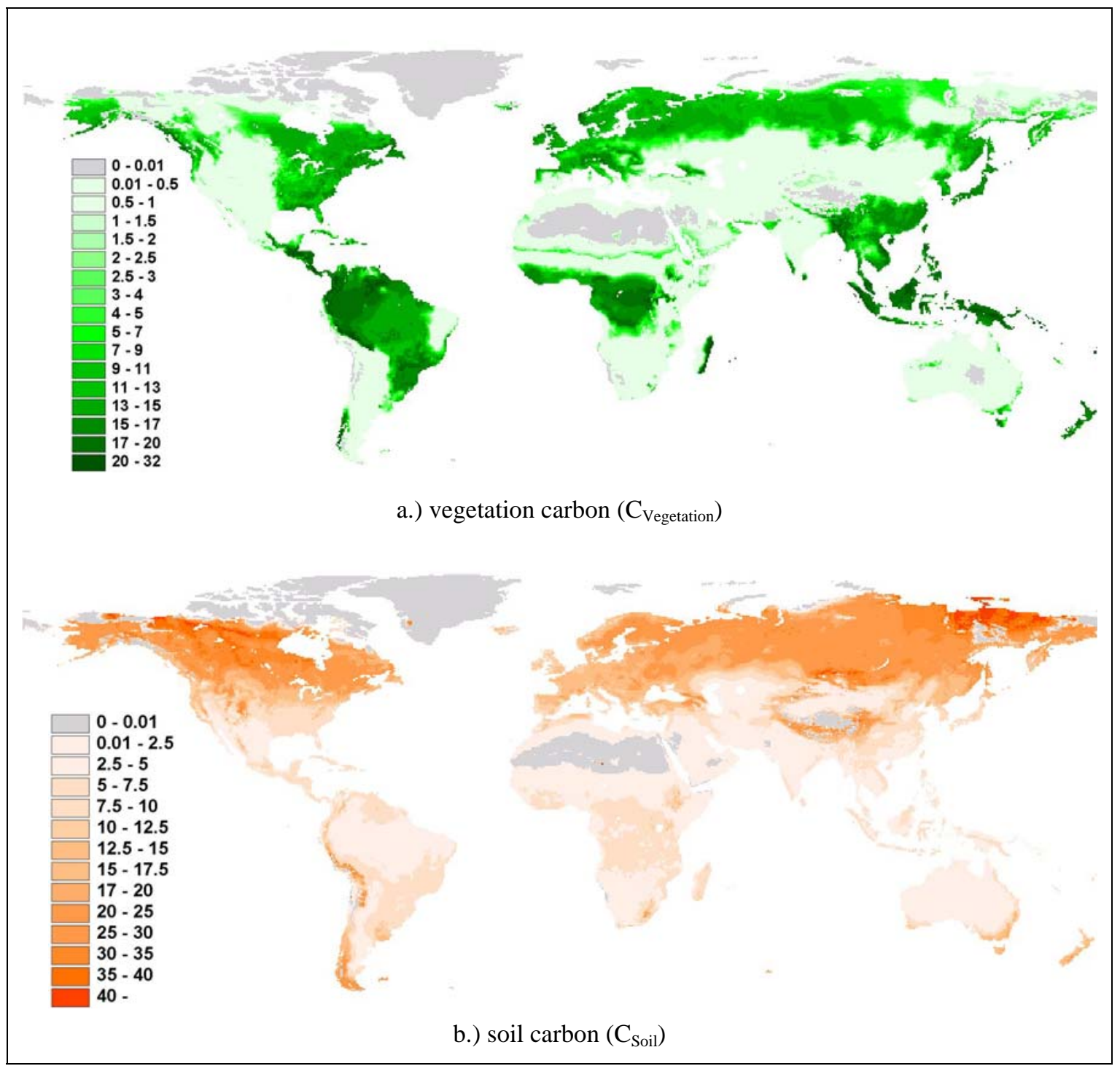

Figure 16. Simulated potential natural areas of vegetation and soil for the 1901-1930 climate. [kgC/m²] 
The distribution of simulated natural vegetation per carbon pool and per continent is presented in numbers in Table 5. Asia together with South and Central America dominate the total vegetation carbon, though also the European continent has rather high vegetation carbon per area. For soil carbon there is a clear dominance for the higher latitudes, explained primarily by the slower decomposition rates as a result of a colder climate.

Table 5. Simulated potential natural vegetation with carbon pools divided per continent [GtC]. Average carbon stock per area given in parenthesis $\left[\mathrm{kgC} / \mathrm{m}^{2}\right]$.

\begin{tabular}{lrrrrrr}
\hline Continent & \multicolumn{2}{c}{ C Vegetation } & \multicolumn{2}{c}{ C $_{\text {Soil }}$} & \multicolumn{2}{c}{ C $_{\text {Litter }}$} \\
\hline Africa & 105 & $(3.5)$ & 102 & $(3.4)$ & 26 & $(0.9)$ \\
Asia & 226 & $(5.0)$ & 526 & $(11.7)$ & 113 & $(2.5)$ \\
Australia & 11 & $(1.3)$ & 29 & $(3.6)$ & 7 & $(0.8)$ \\
Europe & 91 & $(8.8)$ & 172 & $(16.6)$ & 37 & $(3.5)$ \\
North America & 108 & $(5.5)$ & 330 & $(16.9)$ & 69 & $(3.5)$ \\
South and Central America & 203 & $(9.9)$ & 125 & $(6.1)$ & 32 & $(1.6)$ \\
\hline
\end{tabular}

\subsection{Simulated carbon release as a result of human land-use}

The accumulated carbon flux related to the developed land-use data set for the entire simulation period until 1998 was 275 GtC. Until 1850, human land-use resulted in an accumulated carbon release of $114 \mathrm{GtC}$, while $148 \mathrm{GtC}$ was emitted from 1850 until 1990. $91 \%$ of the total carbon release occurred after 2000 BP. (Figure 17; Table 6)

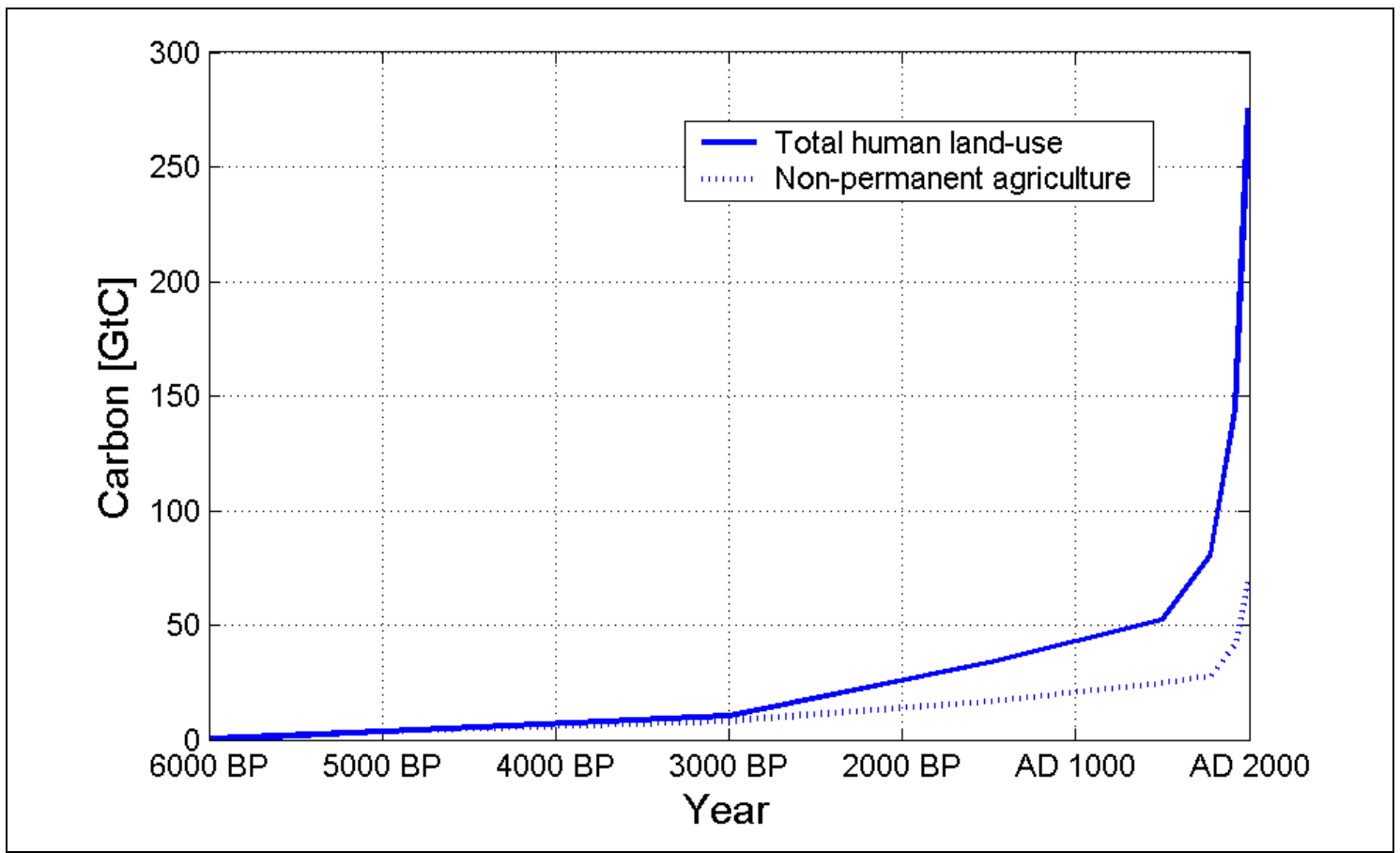

Figure 17. Simulated accumulated carbon release as a result of the applied human land-use during the last 6000 years. [GtC]

Over the full simulation period, the accumulated carbon release from permanent agriculture was $205 \mathrm{GtC}$. Carbon fluxes originating from non-permanent agriculture contributed an additional $71 \mathrm{GtC}$, corresponding to $26 \%$ of the total flux to the atmosphere. Until AD 1500, non-permanent agriculture contributed with $47 \%$ of the released carbon. The relative role of 
permanent agriculture increased with time and was especially noticeable during the two last time-slices. A decrease in vegetation carbon of $217 \mathrm{GtC}$ accounted for $79 \%$ of the accumulated carbon emissions over the entire simulation period. At the same time, the soil carbon pool decreased by $64 \mathrm{GtC}$ and the litter pool increased by 6 GtC. (Figure 17; Table 6)

Table 6. Simulated accumulated carbon pool changes as well as carbon flux divided per land-use mode, by the end of each time-slice, and at selected years. [GtC]

\begin{tabular}{|c|c|c|c|c|c|c|}
\hline \multirow[b]{2}{*}{ Time } & \multicolumn{3}{|c|}{ Carbon pool } & \multicolumn{2}{|c|}{ Land-use mode (flux) } & \multirow[b]{2}{*}{ Total flux } \\
\hline & $\mathbf{C}_{\text {Vegetation }}$ & $\mathbf{C}_{\text {Soil }}$ & $\mathbf{C}_{\text {Litter }}$ & Permanent & Non-perm. & \\
\hline a) $5001 \mathrm{BP}$ & -3.9 & 0.2 & 0.0 & 0.1 & 3.5 & 3.6 \\
\hline b) $3001 \mathrm{BP}$ & -9.8 & -0.5 & 0.0 & 2.0 & 8.3 & 10.3 \\
\hline c) $\mathrm{AD} 499$ & -29.0 & -5.1 & 0.2 & 17.3 & 16.5 & 33.8 \\
\hline d) AD 1499 & -46.0 & -7.0 & 0.8 & 27.5 & 24.8 & 52.3 \\
\hline e) AD 1774 & -61.5 & -18.7 & -0.3 & 52.8 & 27.6 & 80.4 \\
\hline f) $\mathrm{AD} 1920$ & -117.6 & -32.6 & 5.7 & 103.4 & 41.1 & 144.5 \\
\hline g) AD 1998 & -217.3 & -63.7 & 5.6 & 204.9 & 70.6 & 275.4 \\
\hline 2000 BP (estimated) & -22.6 & -3.5 & 0.1 & 12.2 & 13.8 & 26.0 \\
\hline AD 1700 (est.) & -57.2 & -15.5 & 0.0 & 45.9 & 26.9 & 72.7 \\
\hline AD 1850 (est.) & -90.5 & -25.9 & 2.8 & 79.0 & 34.6 & 113.5 \\
\hline AD 1990 (est.) & -207.1 & -60.5 & 5.6 & 194.5 & 67.5 & 262.0 \\
\hline AD 1992 (est.) & -209.6 & -61.3 & 5.6 & 197.1 & 68.3 & 265.3 \\
\hline
\end{tabular}

A geographical data separation of simulated carbon flux per continent for permanent and nonpermanent agriculture is shown in Appendix C (see also data in Appendix A).

The geographical distribution of accumulated carbon flux per grid cell for the entire simulation period is shown in Figure 18. Areas with an accumulated net flux to the atmosphere clearly dominate the general picture. However, a few areas show a net terrestrial uptake, primarily as a result of the applied climatic changes during the $20^{\text {th }}$ century in combination with abandoned agricultural areas that are currently being reforested.

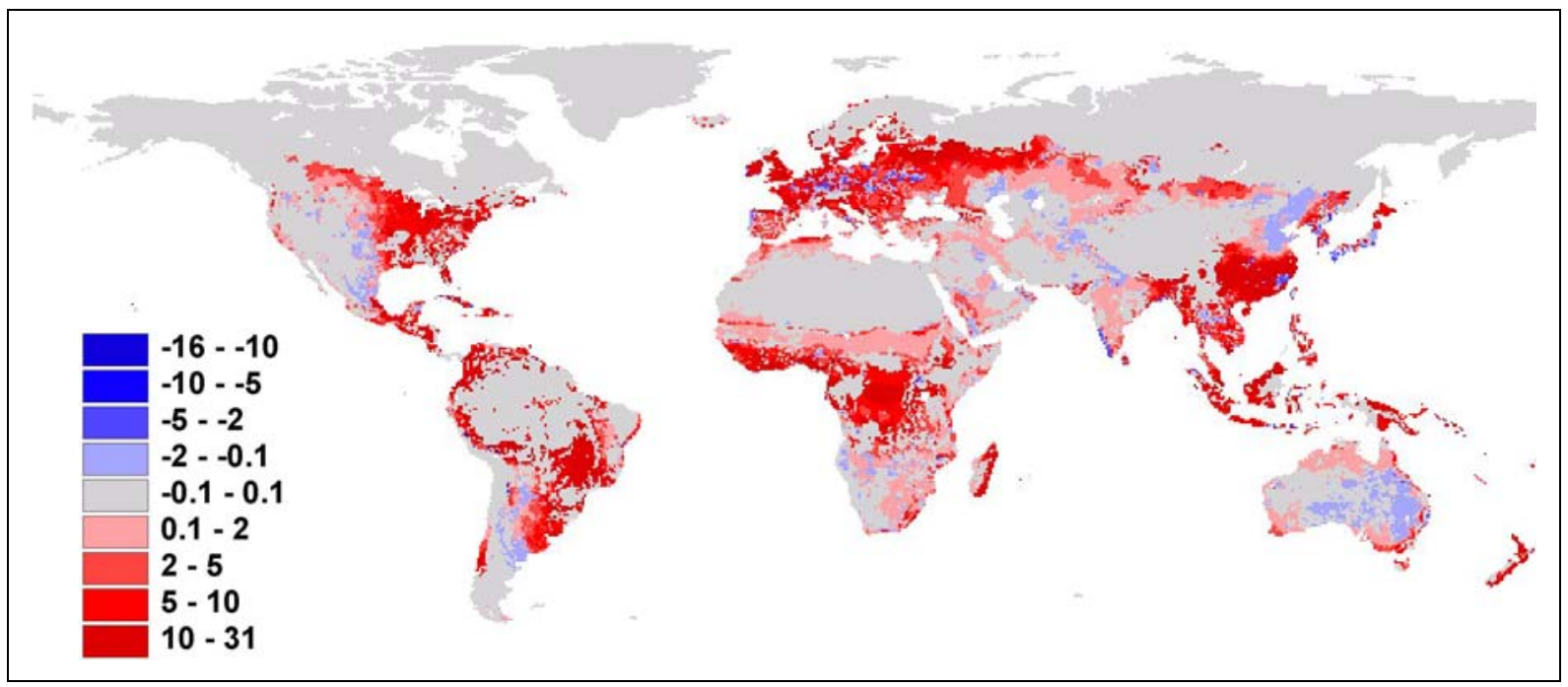

Figure 18. Simulated accumulated carbon flux from 6000 BP until 1998 as a result of the derived land-use data set. Positive values represent a net flux to the atmosphere, while negative values represent a net terrestrial uptake. $\left[\mathrm{kgC} / \mathrm{m}^{2}\right]$ 


\subsection{Comparison with other land-use studies}

Table 7 shows a comparison with other land-use studies (see also Section 1.2; Table 1): for most time periods, the estimated carbon release from permanent agriculture was within the range reported in other studies. At $2000 \mathrm{BP}$, the modelled carbon release was, however, an order of magnitude lower than the estimate from Ruddiman (2003), as a result of considerably smaller areas assigned with land-use by 2000 BP in the present study as well as a lower modelled estimate of carbon loss per area for the regions assigned with agriculture. Compared with the estimate until 1850 by DeFries et al. (1999), the modelled carbon release from permanent agriculture was approximately 50\% higher. Carbon fluxes from non-permanent agriculture added considerably to the carbon releases originating from permanent agriculture during the entire simulated time period, especially before $2000 \mathrm{BP}$.

Table 7. Comparison of the modelled total land-use-change-related global carbon release with estimates from other studies (Section 1.2; Table 1). The results from this study are shown also with the separate contributions from permanent and non-permanent agriculture. [GtC]

\begin{tabular}{llccccc}
\hline Study & $\mathbf{- 2 0 0 0 ~ B P}$ & $\mathbf{1 7 0 0} \mathbf{- 1 9 9 0}$ & $\mathbf{- 1 8 5 0}$ & $\mathbf{1 8 5 0 - \mathbf { 1 9 9 0 }}$ & $\mathbf{- 1 9 9 0}$ & $\mathbf{1 9 2 0} \mathbf{- 1 9 9 2}$ \\
\hline $\begin{array}{l}\text { DeFries } \text { et al. (1999) } \\
\text { McGuire } \text { et al. (2001) }\end{array}$ & & & $48-57$ & & $182-199$ & \\
Houghton (2003a) & & & & & & $56-91$ \\
Ruddiman (2003) & 250 & & 320 & & & \\
Levy et al. (2004) & & 222 & & 173 & & \\
Campos et al. (2005) & & 139 & & 98 & & \\
This study total & 26 & 189 & 114 & 148 & 262 & 121 \\
$\quad$ Permanent & 12 & 148 & 79 & 115 & 194 & 94 \\
$\quad$ Non-permanent & 14 & 41 & 35 & 33 & 68 & 27 \\
\hline
\end{tabular}

\subsection{Vegetation landscape openness}

With less forested land and more land areas being used for cultivation and pasture, there was an increase in vegetation openness induced by human land-use, which can be visualised as a change in forest Leaf Area Index (LAI), see Figure 19. At 2000 BP, a strong human impact on vegetation openness was only obvious in some regions in Europe and Southeast Asia. However, by AD 1990, modelled anthropogenic landscape openness was pronounced in several areas all over the world. (Figure 19)

While interpreting these results, however, it has to be kept in mind that the impacts of nonpermanent agriculture were averaged over the whole area where this farming method was assumed to occur. This explains why the openness maps do not depict more localised effects of early humans. When modelling global total carbon releases, small averaged carbon releases over large areas can still add up to considerable magnitudes. 


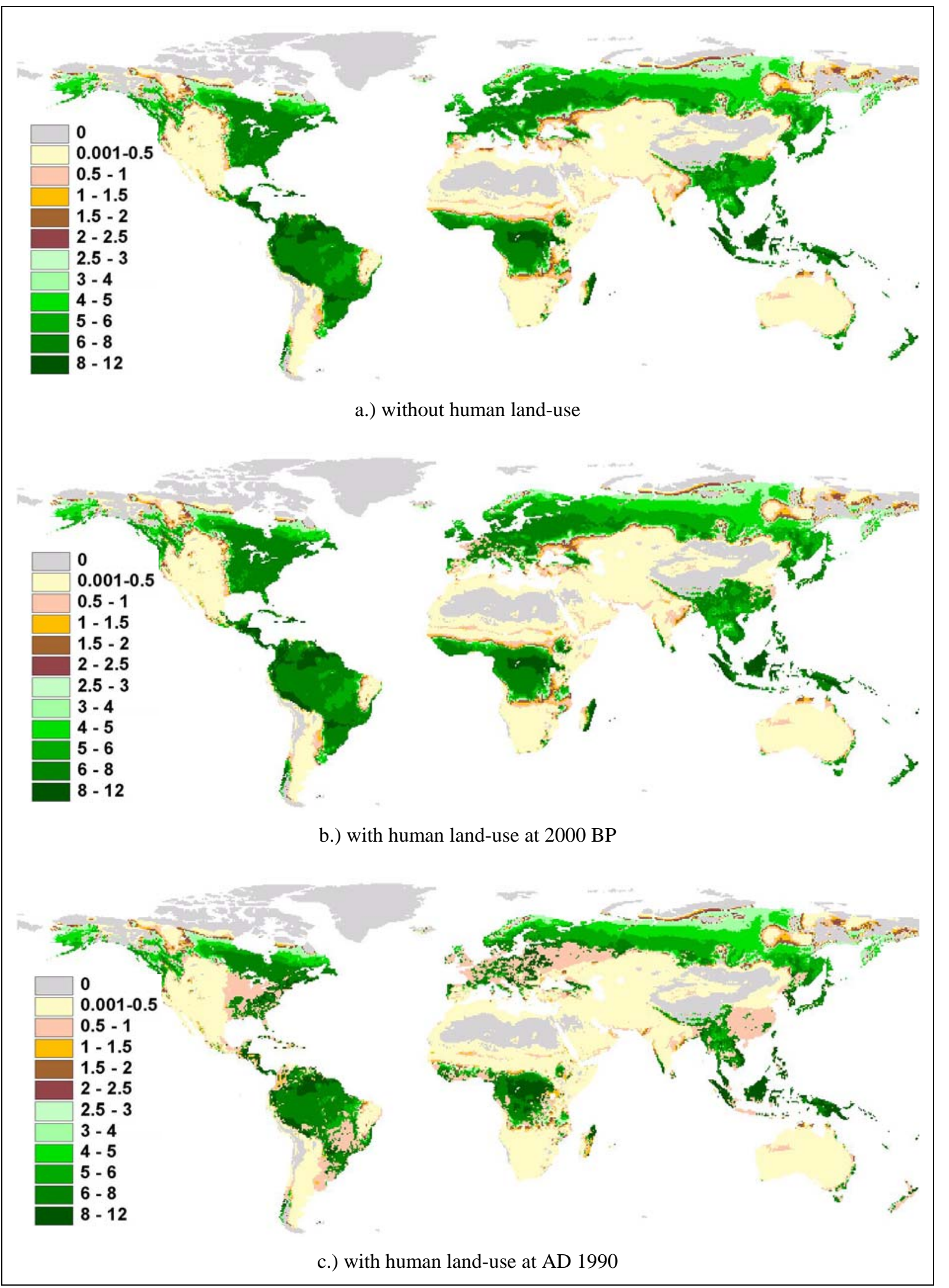

Figure 19. Modelled landscape openness expressed as forest Leaf Area Index (LAI). 



\section{DISCUSSION}

The ever-increasing human presence complicates the task of understanding the development of the Earth system since the end of the latest glacial. Foley et al. (2005) noted that land-use in general has been regarded as a local environmental issue but is at the present becoming a matter of global importance driven by the increasing needs of a growing human population.

The hypothesis of Ruddiman (2003) that a human impact on climate, through an extensive deforestation far prior to the industrial era, connects early land-use to global climate change. Already Sagan et al. (1979) related human land-use via albedo changes to climate variations and found it possible that humans have contributed considerably to induce global climate shifts in the past millennia and maybe as early as a million years ago.

Early land-use might thus be a more important parameter for understanding the climate and the global carbon cycle than has been previously thought. Land-use history is important for correctly assessing the effects of past land-use on the development of current soil carbon pools because of the slow decomposition rates involved (Houghton \& Goodale 2004).

The present study using a dynamic global vegetation model including an extended land-use history should therefore be seen as a further attempt in investigating a possible early anthropogenic impact on the Earth system. As remarked already, this study has focused on land-use and related $\mathrm{CO}_{2}$ fluxes, and thus carbon fluxes in the form of $\mathrm{CH}_{4}$ from, e.g., irrigated rice-paddies, were not included as well as other human land-uses such as forestry.

\subsection{Carbon release from human land-use}

This study presents a first estimate of dynamic changes in carbon emissions during the last 6000 years caused by land-use, including non-permanent agriculture, and thus goes considerably further back in time than previous global studies, which have mainly focused only on the last 300 years. The results suggest the same magnitude of carbon release from permanent agriculture as presented in other studies based on process models (Section 1.2; Table 7), but indicate a considerable additional contribution from non-permanent agriculture.

The modelled fractional decrease in soil carbon as a result of farming was similar in magnitude to the figure suggested by Houghton \& Goodale (2004). The modelled average annual carbon release during 1920 until 1998 from permanent and non-permanent agriculture

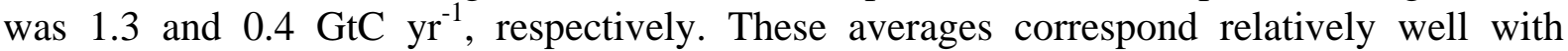
estimates from Houghton (2003a) that land-use change and management in the 1990s caused

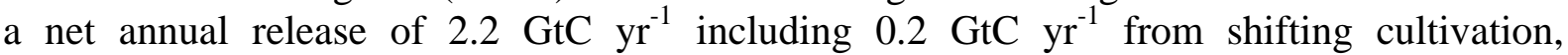
considering an increased land-use impact with time during the last modelled time-slice.

The long calculated fallow periods (Table 3) during the initial time-slices correspond to the theory of Iversen's landnám phases ${ }^{11}$ of forest clearance (Iversen 1941 in Roberts 1998), which might have lasted up to 600 years (Smith 1981 in Roberts 1998), although a repetition of the clearance cycle is seldom seen in Neolithic pollen diagrams (Roberts 1998). The trend of shortening fallow periods over time is consistent with an increasing food production because of a growing human population, as observed during medieval times in Europe

\footnotetext{
${ }^{11}$ The process when man stopped being hunters/collectors and started to "take possession of the land" for pasture and agriculture, a development at least initially resembling of shifting cultivation (see p 155 in Roberts 1998).
} 
(Williams 2000) and in modern non-permanent agriculture societies (Fearnside 2000; Metzger 2003).

\subsubsection{Results relating to Ruddiman's hypothesis}

By 2000 BP, the present study indicates an accumulated total carbon release from land-use of $26 \mathrm{GtC}$ (Table 6), which is considerably less than the $250 \mathrm{GtC}$ originally suggested by Ruddiman (2003), recently modified to "perhaps a third" of the total $\mathrm{CO}_{2}$ anomaly compared with earlier interglacials (Ruddiman 2005a) corresponding to about $200 \mathrm{GtC}$ (Ruddiman 2005c) based on Joos et al. (2004). According to Joos et al. (2004), an even higher anthropogenic emission (710 GtC until present) would have been necessary for the strong influence on atmospheric $\mathrm{CO}_{2}$ suggested by Ruddiman (Section 1.1).

A human-induced direct release of $26 \mathrm{GtC}$ would correspond to an atmospheric $\mathrm{CO}_{2}$ increase of about 1.8 ppmv following the calculations in Joos et al. (2004) ${ }^{12}$, which is a factor 20 less than Ruddiman's initial hypothesis (40 ppmv). This study therefore suggests that a strong influence of land-use-related carbon emissions before 2000 BP is unlikely (Figure 17).

These findings call for an alternative explanation for the current relatively long interglacial, compared with the last three warm periods: the current low eccentricity of the Earths' orbit might be the reason for the long warm period (Broecker \& Stocker 2006). When a similar eccentricity as today prevailed about 400 thousand years BP (Marine Isotope Stage [MIS] 11), atmospheric $\mathrm{CO}_{2}$ levels stayed at interglacial levels, above $270 \mathrm{ppmv}$, for 28,000 years (Siegenthaler et al. 2005; Broecker \& Stocker 2006).

\subsection{Uncertainties}

In summary, the results are generally consistent with findings from other studies on the involved processes. However, it has to be acknowledged that some of the parameter values used to implement non-permanent human land-use are subject to some uncertainty. Zaehle et al. (2005) investigated general parameter uncertainties for LPJ-DGVM and found that the soil carbon pools represented the most uncertain model output as a result of their long turnover times. After carrying out a number of alternative simulations for the study presented here, with modifications in the land-use implementation such as variations in areas under nonpermanent agriculture and fallow period lengths, there is a certain confidence that the presented results are generally robust.

At this stage, two shortcomings of the current study need to be emphasised: the approach was developed to derive an objective estimate of global total carbon releases, including considerable averaging of human impacts over large areas. When zooming into a particular area, for example by analysing the modelled spatial pattern of landscape openness, the model may not adequately represent the human fingerprint on the landscape. As spatial data on global human population densities are not yet available for the period before 1700, it might however be difficult to account for this real-world heterogeneity when using a global, quantitative modelling approach.

Secondly, human effects on ecosystems that are not directly related to agriculture were not included. Native North American Indians, for example, have used fire to open up the forest for thousands of years to provide better opportunities for hunting, thereby potentially

\footnotetext{
${ }^{12} 0.15 *(26$ [GtC] / 2.123 [GtC/ppmv]) [85\% of the emitted carbon removed by the ocean (Joos et al. 2004)]
} 
maintaining an open prairie instead of partly forested woodlands (Anderson 1987). Managed forestry, which currently influences large areas of the global forests, was neither considered in this study.

An additional potential factor to consider is soil erosion, which is estimated to presently cause



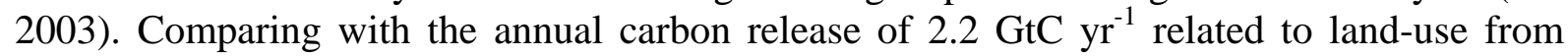
Houghton \& Goodale (2004), soil erosion might therefore substantially increase the estimated carbon flux from human agricultural activities.

Other examples of potential factors not yet incorporated are effects of large-scale irrigation that influences crop growth and the hydrological balance, as well as fertilizers used to improve the crop yields (LPJ-DGVM does not yet include nutrient dynamics and limitations). The effect of grazing animals on the carbon balance would also be interesting to examine. However, all these potential factors need to be further investigated before they can be applied in a future re-assessment modelling study (Section 6.2).

Finally, it is important to again recall that this study has included only $\mathrm{CO}_{2}$ fluxes caused by land-use and thus not considered carbon fluxes in the form of $\mathrm{CH}_{4}$. However, carbon fluxes related to land-use induced $\mathrm{CH}_{4}$ are approximated to be considerably lower than the $\mathrm{CO}_{2}$ fluxes and would thus most likely have contributed only slightly to the global carbon development during the studied period. 



\section{ConClusions}

\subsection{Key findings}

The main conclusions from the land-use modelling study covering the last 6000 years were:

- Most carbon emissions occurred after 1850, even when including accumulated early nonpermanent agriculture.

- Non-permanent agriculture caused about $25 \%$ of total carbon emissions, making a significant addition to fluxes from human land-use and thus indicating the importance of including more than permanent agriculture in carbon and land-use related studies.

- Changes in the soil carbon pool contributed with $23 \%$ of the emissions, stressing the importance to include more than changes in vegetation when studying land-use as well as the importance of including land-use history because of the slow soil decomposition rates.

- No major early human-induced impact on global climate was found and consequently the results suggest that the hypothesis of Ruddiman is unlikely.

\subsection{Future research}

As this was a first study of estimating the global impact on the carbon cycle from early dynamic human land-use, there are several potentials for improvements in future research including detailed sensitivity tests of extreme land-use alternatives. Applying "real" climate and $\mathrm{CO}_{2}$ data (see Appendix $\mathrm{B}$ ) for the entire simulation period would improve the modelled estimate of growth conditions, but would probably not have a considerable effect on the results. Feedback mechanisms between changes in climate and vegetation cover through landuse requiring a fully coupled Earth system model would be another interesting investigation to perform with the developed land-use set up.

However, a further development in obtaining the land-use data set is probably more important for the modelling results. The land-use data set could be divided into more time-slices for a finer representation of the land-use development for the pre-industrial period as well as applying more already developed time-slices from the HYDE data set for the last 300 years.

A closer connection to actual spatial distribution and population density of humanity during the Holocene could be accomplished through using more detailed information about the human population density available from, e.g., archaeology, pollen sediments and recorded historical sources, and would thereby certainly improve the procedure of spatial assigning the land-use modes. Additional modules of other human-related land-use, such as forestry and grazing, could also be developed and integrated into the model. Furthermore, spatial and temporal variations in farming practices and crops based on local conditions (e.g., soil, topography and hydrology) could as well be integrated in a more detailed future study. 



\section{ACKNOWLEDGEMENTS}

I would like to give a very special thanks to my supervisor Thomas Hickler for giving lots of inspiration and support during my work. Always patient to discuss tricky technical difficulties and providing invaluable advises in the programming jungle. Thanks also for all assistance during the process of finding helpful background material for developing the data set and never-ending encouragement when writing this report. TACK!

Furthermore, I would like to thank Professor Martin Sykes for opening up my eyes for ecosystem modelling and for nicely giving me the opportunity to present my work at the joint HITE-POLLANDCAL conference in Umeå. A special thanks also to PhD-student Janno Tuulik for great assistance in handling SIMBA, the computer cluster at the department used for executing the global simulations.

Last but not least, I would like to thank all great fellow students at the Department of Physical Geography and Ecosystem Analysis, my friends and my family. 



\section{REFERENCES}

Adams JM, Faure H (1998) A new estimate of changing carbon storage on land since the last glacial maximum, based on global land ecosystem reconstruction. Global and Planetary Change 16-17:3-24

Alley RB, Ágústsdóttir AM (2005) The 8k event: cause and consequences of a major Holocene abrupt climate change. Quaternary Science Reviews 24:1123-1149

Andersen KK, Azuma N, Barnola J-M, Bigler M, Biscaye P, Caillon N, Chappellaz J, Clausen HB, Dahl-Jensen D, Fischer H, Flückiger J, Fritzsche D, Fujii Y, Goto-Azuma K, Grønvold K, Gundestrup NS, Hansson M, Huber C, Hvidberg CS, Johnsen SJ, Jonsell U, Jouzel J, Kipfstuhl S, Landais A, Leuenberger M, Lorrain R, Masson-Delmotte V, Miller H, Motoyama H, Narita H, Popp T, Rasmussen SO, Raynaud D, Rothlisberger R, Ruth U, Samyn D, Schwander J, Shoji H, Siggard-Andersen M-L, Steffensen JP, Stocker T, Sveinbjörnsdóttir AE, Svensson A, Takata M, Tison J-L, Thorsteinsson Th, Watanabe O, Wilhelms F, White JWC (2004) Highresolution record of Northern Hemisphere climate extending into the last interglacial period. Nature 431:147-151

Anderson RC (1987) The historic role of fire in the North American grassland. In: Collins SL, Wallace (eds) Fire in North American Tallgrass Prairies. University of Oklahoma Press, Norman, pp 9-18

Archer D, Winguth A, Lea D, Mahowald N (2000) What caused the glacial/interglacial atmospheric $\mathrm{pCO}_{2}$ cycles? Reviews of Geophysics 38:159-189

Augustin L, Barbante C, Barnes PRF, Barnola JM, Bigler M, Castellano E, Cattani O, Chappellaz J, Dahl-Jensen D, Delmonte B, Dreyfus G, Durand G, Falourd S, Fischer H, Flückiger J, Hansson ME, Huybrechts P, Jugie R, Johnsen SJ, Jouzel J, Kaufmann P, Kipfstuhl J, Lambert F, Lipenkov VY, Littot GVC, Longinelli A, Lorrain R, Maggi V, Masson-Delmotte V, Miller H, Mulvaney R, Oerlemans J, Oerter H, Orombelli G, Parrenin F, Peel DA, Petit JR, Raynaud D, Ritz C, Ruth U, Schwander J, Siegenthaler U, Souchez R, Stauffer B, Steffensen JP, Stenni B, Stocker TF, Tabacco IE, Udisti R, Van de Wal RSW, Van den Broeke M, Weiss J, Wilhelms F, Winther JG, Wolff EW, Zucchelli M (2004) Eight glacial cycles from an Antarctic ice core. Nature 429:623-628

Beer J, Mende W, Stellmacher R (2000) The role of the sun in climate forcing. Quaternary Science Reviews 19:403-415

Berglund BE (2003) Human impact and climate changes - synchronous events and a causal link? Quaternary International 105:7-12

Bonan G (2002) Ecological Climatology: Concepts and Applications. Cambridge University Press, Cambridge

Bondeau A, Smith P, Zaehle S, Schaphoff S, Lucht W, Cramer W, Gerten D, Lotze-Campen H, Müller C, Reichstein M, Smith B (2006) Modelling the role of agriculture for the 20th century global terrestrial carbon cycle. Submitted to Global Change Biology

Bradley RS (2000) Past global changes and their significance for the future. Quaternary Science Reviews 19:391-402

Brady NC (1996) Alternatives to slash-and-burn: a global imperative. Agriculture, Ecosystems and Environment 58:3-11

Brázdil R, Pfister C, Wanner H, Von Storch H, Luterbacher J (2005) Historical climatology in Europe - The state of the art. Climatic Change 70:363-430

Broecker WS, Stocker TF (2006) The Holocene $\mathrm{CO}_{2}$ rise: Anthropogenic or natural? EOS 87(3):27-28

Brovkin V, Claussen M, Driesschaert E, Fichefet T, Kicklighter D, Loutre MF, Matthews HD, Ramankutty N, Schaeffer M, Sokolov A (2006) Biogeophysical effects of historical land cover changes simulated by six Earth system models of intermediate complexity. Climate Dynamics 26:587-600 DOI 10.1007/s00382-005-0092-6

Campos CP, Muylaert MS, Rosa LP (2005) Historical $\mathrm{CO}_{2}$ emission and concentrations due to land use change of croplands and pastures by country. Science of the Total Environment 346:149-155

Carcaillet C, Almquist H, Asnong H, Bradshaw RHW, Carrión JS, Gaillard M-J, Gajewski K, Haas JN, Haberle SG, Hadorn P, Müller SD, Richard PJH, Richoz I, Rösch M, Sánchez Gõni MF, Von Stedingk H, Stevenson AC, Talon B, Tardy C, Tinner W, Tryterud E, Wick L, Willis KJ (2002) Holocene biomass burning and global dynamics of the carbon cycle. Chemosphere 49:845-863 
Clark JS, Merkt J, Müller H (1989) Post-glacial fire, vegetation, and human history on the Northern alpine forelands, South-Western Germany. Journal of Ecology 77:897-925

Claussen M, Brovkin V, Calov R, Ganopolski A, Kubatzki C (2005) Did humankind prevent a Holocene glaciation? Climatic Change 69:409-417

Crucifix M, Loutre M-F, Berger A (2005) Commentary on “The anthropogenic greenhouse era began thousands of years ago". Climatic Change 69:419-426

Crutzen PJ, Andreae MO (1990) Biomass burning in the tropics: Impact on atmospheric chemistry and biogeochemical cycles. Science 250:1669-1678

Crutzen PJ, Stoermer EF (2000) The Anthropocene. IGBP Newsletter 41:12-13

DeFries RS, Field CB, Fung I, Collatz GJ, Bounoua L (1999) Combining satellite data and biogeochemical models to estimate global effects of human-induced land cover change on carbon emissions and primary productivity. Global Biogeochemical Cycles 13:803-815

Diamond J (1997) Guns, germs and steel - a short history of everybody for the last 13000 years. Chatto and Windus, London

Doolittle WE (2004) Permanent vs. shifting cultivation in the Eastern Woodlands of North America prior to European contact. Agriculture and Human Values 21:77-85

Easterling DR, Meehl GA, Parmesan C, Changnon SA, Karl TR, Mearns LO (2000) Climate extremes: Observations, modeling, and impacts. Science 289:2068-2074

Etheridge DM, Steele LP, Langenfelds RL, Francey RJ, Barnola J-M, Morgan VI (1996) Natural and anthropogenic changes in atmospheric $\mathrm{CO}_{2}$ over the last 1000 years from air in Antarctic ice and firn. Journal of Geophysical Research 101:4115-4128

[2005-11-18: http://www1.ncdc.noaa.gov/pub/data/paleo/icecore/antarctica/law/law_co2.txt]

Falkowski P, Scholes RJ, Boyle E, Canadell J, Canfield D, Elser J, Gruber N, Hibbard K, Högberg P, Linder S, Mackenzie FT, Moore III B, Pedersen T, Rosenthal Y, Seitzinger S, Smetacek V, Steffen W (2000) The Global Carbon Cycle: A Test of Our Knowledge of Earth as a System. Science 290:291-296

FAO (Food and Agriculture Organization) (1991) The digitized soil map of the world (release 1.0). FAO, Rome

Fearnside PM (2000) Global warming and tropical land-use change: Greenhouse gas emissions from biomass burning, decomposition and soils in forest conversion, shifting cultivation and secondary vegetation. Climatic Change 46:115-158

Foley JA, Costa MH, Delire C, Ramankutty N, Snyder P (2003) Green surprise? How terrestrial ecosystems could affect earth's climate. Frontiers in Ecology and the Environment 1:38-44

Foley JA, DeFries R, Asner GP, Barford C, Bonan G, Carpenter SR, Chapin FS, Coe MT, Daily GC, Gibbs HK, Helkowski JH, Holloway T, Howard EA, Kucharik CJ, Monfreda C, Patz JA, Prentice IC, Ramankutty N, Snyder PK (2005) Global consequences of land use. Science 309:570-574

Gerten D, Schaphoff S, Haberlandt U, Lucht W, Sitch S (2004) Terrestrial vegetation and water balance hydrological evaluation of a dynamic global vegetation model. Journal of Hydrology 286:249-270

Giardina CP, Sanford RL, Døckersmith IC, Jaramillo VJ (2000) The effects of slash burning on ecosystem nutrients during the land preparation phase of shifting cultivation. Plant and Soil 220:247-260

Gordon C, Cooper C, Senior CA, Banks H, Gregory JM, Johns TC, Mitchell JFB, Wood RA (2000) The simulation of SST, sea ice extents and ocean heat transports in a version of the Hadley Centre coupled model without flux adjustments. Climate Dynamics 16:147-168

Gordon LJ, Steffen W, Jönsson BF, Folke C, Falkenmark M, Johannessen Å (2005) Human modification of global water vapor flows from the land surface. Proceedings of the National Academy of Science 102:7612-7617

Grigg DB (1974) The Agricultural Systems of the World - An Evolutionary Approach. Cambridge University Press, Cambridge 
Guo LB, Gifford RM (2002) Soil carbon stocks and land use changes: a meta analysis. Global Change Biology 8:345-360

Gupta AK (2004) Origin of agriculture and domestication of plants and animals linked to early Holocene climate amelioration. Current Science 87:54-59

Hays JD, Imbrie J, Shackelton NJ (1976) Variations in the Earth's orbit: Pacemaker of the ice ages. Science 194:1121-1132

Hickler T, Prentice IC, Smith B, Sykes MT, Zaehle S (2006) Implementing plant hydraulic architecture within the LPJ Dynamic Global Vegetation Model. Global Ecology and Biogeography In press

Houghton J (2005a) Global warming. Reports on Progress in Physics 68:1343-1403 DOI:10.1088/00344885/68/6/R02

Houghton RA, Hobbie JE, Melillo JM, Moore B, Peterson BJ, Shaver GR, Woodwell GM (1983) Changes in the carbon content of terrestrial biota and soils between 1860 and 1980: A net release of $\mathrm{CO}_{2}$ to the atmosphere. Ecological Monographs 53:235-262

Houghton RA (1999) The annual net flux of carbon to the atmosphere from changes in land use 1850-1990. Tellus 51B:298-313

Houghton RA (2003a) Revised estimates of the annual net flux of carbon to the atmosphere from changes in land use and land management 1850-2000. Tellus 55B:378-390

Houghton RA (2003b) Why are estimates of the terrestrial carbon balance so different? Global Change Biology 9:500-509

Houghton RA, Goodale CL (2004) Effects of land-use change on the carbon balance of terrestrial ecosystems. In: DeFries R, Asner G, Houghton R (eds) Ecosystems and Land Use Change. Geophysical Monograph Series 153, American Geophysical Union, Washington DC

Houghton RA (2005b) Aboveground forest biomass and the global carbon balance. Global Change Biology 11:945-958

House JI, Prentice IC, Le Quéré C (2002) Maximum impacts of future reforestation or deforestation on atmospheric $\mathrm{CO}_{2}$. Global Change Biology 8:1047-1052

House JI, Prentice IC, Ramankutty N, Houghton RA, Heimann M (2003) Reconciling apparent inconsistencies in estimates of terrestrial $\mathrm{CO}_{2}$ sources and sinks. Tellus 55B:345-363

Indermühle A, Stocker TF, Joos F, Fischer H, Smith HJ, Wahlen M, Deck B, Mastroianni D (1999) Holocene carbon-cycle dynamics based on $\mathrm{CO}_{2}$ trapped in ice at Taylor Dome, Antarctica. Nature 398:121-126 [2005-11-18: http://www1.ncdc.noaa.gov/pub/data/paleo/icecore/antarctica/taylor/taylor_co2-holocene.txt]

Jones PD, Mann ME (2004) Climate over past millennia. Reviews of Geophysics 42:RG2002 DOI 10.1029/2003RG000143

Joos F, Gerber S, Prentice IC, Otto-Bliesner BL, Valdes PJ (2004) Transient simulations of Holocene atmospheric carbon dioxide and terrestrial carbon since the Last Glacial Maximum. Global Biogeochemical Cycles 18:GB2002 DOI 10.1029/2003GB002156

Kaplan JO, Prentice IC, Knorr W, Valdes PJ (2002) Modeling the dynamics of terrestrial carbon storage since the Last Glacial Maximum. Geophysical Research Letters 29 DOI 10.1029/2002GL015230

Karl TR, Trenberth KE (2003) Modern global climate change. Science 302:1719-1723

Keeling CD, Whorf TP (2005) Atmospheric $\mathrm{CO}_{2}$ concentrations (ppmv) derived from in situ air samples collected at Mauna Loa Observatory, Hawaii. Scripps Institution of Oceanography (SIO), University of California, La Jolla, California [2005-11-18: http://cdiac.ornl.gov/ftp/trends/co2/maunaloa.co2]

Klein Goldewijk K (2001) Estimating global land use change over the past 300 years: The HYDE Database. Global Biogeochemical Cycles 15:417-433

Köhler P, Fischer H (2004) Simulating changes in the terrestrial biosphere during the last glacial/interglacial transition. Global and Planetary Change 43:33-55 
Lal R (2003) Soil erosion and the global carbon budget. Environment International 29:437-450

Lanly JP (1985) Defining and measuring shifting cultivation. Unasylva 37:17-21

Levy PE, Friend AD, White A, Cannell MGR (2004) The influence of land use change on global-scale fluxes of carbon from terrestrial ecosystems. Climatic Change 67:185-209

Lewthwaite JW, Sherratt A (1980) Chronological Atlas. In: Sherratt A (ed) Cambridge Encyclopedia of Archeology. Cambridge University Press, Cambridge

Lucht W, Prentice IC, Myneni RB, Sitch S, Friedlingstein P, Cramer W, Bousquet P, Buermann W, Smith B (2002) Climatic control of the high-latitude vegetation greening trend and Pinatubo effect. Science 296:16871689

Malhi Y, Meir P, Brown S (2002) Forests, carbon and global climate. Philosophical Transactions of the Royal Society of London Series A: Mathematical, Physical and Engineering Sciences 360:1567-1591

Mann ME, Bradley RS, Hughes MK (1998) Global-scale temperature patters and climate forcing over the past six centuries. Nature 392:779-787

Mason B (2004) The hot hand of history. Nature 427:582-583

Marland G, Andres B, Boden T (2006) Global $\mathrm{CO}_{2}$ Emissions from Fossil-Fuel Burning, Cement Manufacture, and Gas Flaring: 1751-2002. Carbon Dioxide Information Analysis Center, Oak Ridge National Laboratory, Tennessee [2006-06-16: http://cdiac.esd.ornl.gov/ftp/ndp030/global.1751_2003.ems]

Matson PA, Parton WJ, Power AG, Swift MJ (1997) Agricultural intensification and ecosystem properties. Science 277:504-508

Mayewski PA, Rohling EE, Stager JC, Karlén W, Maasch KA, Meeker LD, Meyerseon EA, Gasse F, Von Kreveld S, Holmgren K, Lee-Thorp J, Rosqvist G, Rack F, Staubwasser M, Schneider RR, Steig EJ (2004) Holocene climate variability. Quaternary Research 62:243-255

McCarthy JJ, Canziani OF, Leary NA, Dokken DJ, White KS (eds) (2001) Climate Change 2001: Impacts, Adaptation, and Vulnerability. Cambridge University Press, Cambridge

McEvedy C, Jones R (1978) Atlas of World Population History. Facts on File, New York, pp. 342-351

McGuire AD, Sitch S, Clein JS, Dargaville R, Esser G, Foley J, Heimann M, Joos F, Kaplan J, Kicklighter DW, Meier RA, Melillo JM, Moore III B, Prentice IC, Ramankutty N, Reichenau T, Schloss A, Tian H, Williams LJ, Wittenberg U (2001) Carbon balance of the terrestrial biosphere in the twentieth century: Analysis of $\mathrm{CO}_{2}$, climate and land use effects with four process-based ecosystem models. Global Biogeochemical Cycles 15:183206

Metzger JP (2003) Effects of slash-and-burn fallow periods on landscape structure. Environmental Conservation 30:325-333

Mitchell FJG (2005) How open were European primeval forests? Hypothesis testing using palaeoecological data. Journal of Ecology 93:168-177

Moberg A, Sonechkin DM, Holmgren K, Datsenko NM, Karlén W (2005) Highly variable Northern Hemisphere temperatures reconstructed from low- and high-resolution proxy data. Nature 433:613-617

Monnin E, Indermühle A, Dällenbach A, Flückiger J, Stauffer B, Stocker TF, Raynaud D, Barnola J-M (2001) Atmospheric $\mathrm{CO}_{2}$ concentrations over the last glacial termination Science 291:112-114

Monnin E, Steig EJ, Siegenthaler U, Kawamura K, Schwander J, Stauffer B, Stocker TF, Morse DL, Barnola JM, Bellier B, Raynaud D, Fischer H (2004) Evidence for substantial accumulation rate variability in Antarctica during the Holocene, through synchronization of $\mathrm{CO}_{2}$ in the Taylor Dome, Dome $\mathrm{C}$ and DML ice cores. Earth and Planetary Science Letters 224:45-54

[2005-11-18: http://www1.ncdc.noaa.gov/pub/data/paleo/icecore/antarctica/epica_domec/edc-co2.txt]

New M, Hulme M, Jones PD (1999) Representing twentieth-century space-time climate variability. Part I: Development of a 1961-90 mean monthly terrestrial climatology. Journal of Climate 12:829-856 
New M, Hulme M, Jones PD (2000) Representing twentieth-century space-time climate variability. Part II: Development of 1901-96 monthly grids of terrestrial surface climate. Journal of Climate 13:2217-2238

O’Hare G, Johnson A, Pope R (2005) Current shifts in abrupt climate change: The stability of the North Atlantic Conveyor and its influence on future climate. Geography 90:250-266

Paul KI, Polglase PJ, Nyakuengama JG, Khanna PK (2002) Change in soil carbon following afforestation. Forest Ecology and Management 168:241-257

Pearson PN, Palmer MR (2000) Atmospheric carbon dioxide concentrations over the past 60 million years. Nature 406:695-699

Petit JR, Jouzel J, Raynaud D, Barkov NI, Barnola J-M, Basile I, Bender M, Chappellaz J, Davisk M, Delaygue G, Delmotte M, Kotlyakov VM, Legrand M, Lipenkov VY, Lorius C, Pépin L, Ritz C, Saltzmank E, Stievenard M (1999) Climate and atmospheric history of the past 420,000 years from the Vostok ice core, Antarctica. Nature 399:429-436

[2005-11-18: http://www1.ncdc.noaa.gov/pub/data/paleo/icecore/antarctica/vostok/co2nat.txt]

Pielke Sr RA, Marland G, Betts RA, Chase TN, Eastman JL, Niles JO, Niyogi DDS, Running SW (2002) The influence of land-use change and landscape dynamics on the climate system: relevance to climate-change policy beyond the radiative effect of greenhouse gases. Philosophical Transactions of the Royal Society of London Series A: Mathematical, Physical and Engineering Sciences 360:1705-1719

Pielke Sr RA (2005) Land use and climate change. Science 310:1625-1626

Pimm SL, Raven P (2000) Extinction by numbers. Nature 403:843-845

Prentice IC, Cramer W, Harrison SP, Leemans R, Monserud RA, Solomon AM (1992) A global biome model based on plant physiology and dominance, soil properties and climate. Journal of Biogeography 19:117-134

Prentice IC, Jolly D and BIOME 6000 participants (2000) Mid-Holocene and glacial-maximum vegetation geography of the northern continents and Africa. Journal of Biogeography 27:507-519

Prentice IC, Farquhar GD, Fasham MJ, Goulden MI, Heimann M, Jaramillo VJ, Kheshgi HS, LeQuéré C, Scholes RJ, Wallace DWR (2001) The carbon cycle and atmospheric $\mathrm{CO}_{2}$. In: Houghton JT, Ding Y, Griggs D, Noguer M, Van der Linden P, Dai X, Maskell K, Johnson CA (eds) Climate change 2001: The scientific basis (Contribution of Working Group I to the Third Assessment Report of the Intergovernmental Panel on Climate Change). Cambridge University Press, Cambridge, pp 183-237

Ramankutty N, Foley JA (1999) Estimating historical changes in global land cover: Croplands from 1700 to 1992. Global Biogeochemical Cycles 13:997-1027

Ren G (2000) Decline of the mid- to late Holocene forests in China: Climatic change or human impact? Journal of Quaternary Science 15:273-281

Ren G, Beug H-J (2002) Mapping Holocene pollen data and vegetation of China. Quaternary Science Reviews 21:1395-1422

Roberts N (1998) The Holocene: An Environmental History. Blackwell, Oxford

Ruddiman WF (2001) Earth’s Climate - Past and Future. W.H. Freeman and Company, New York

Ruddiman WF, Thomson JS (2001) The case for human causes of increased atmospheric $\mathrm{CH}_{4}$ over the last 5000 years. Quaternary Science Reviews 20:1769-1777

Ruddiman WF (2003) The anthropogenic greenhouse era began thousands of years ago. Climatic Change 61:261-293

Ruddiman WF (2005a) The early anthropogenic hypothesis a year later. Climatic Change 69:427-434

Ruddiman WF (2005b) Plows, Plagues, and Petroleum: How Humans Took Control of Climate. Princeton University Press, Princeton

Ruddiman WF (2005c) Cold climate during the closest Stage 11 analog to recent Millennia. Quaternary Science Reviews 24:1111-1121 
Rundgren M, Björck S, Hammarlund D (2005) Last interglacial atmospheric $\mathrm{CO}_{2}$ changes from stomatal index data and their relation to climate variations. Global and Planetary Change 49:47-62

Sagan C, Toon OB, Pollack JB (1979) Anthropogenic albedo changes and the Earth’s climate. Science 206:1363-1368

Saunders DA, Hobbs RJ, Margules CR (1991) Biological consequences of ecosystem fragmentation: A review. Conservation Biology 5:18-32

Sherratt A (ed) (1980) The Cambridge Encyclopedia of Archaeology. Cambridge University Press, Cambridge

Siegenthaler U, Stocker TF, Monnin E, Lüthi D, Schwander J, Stauffer B, Raynaud D, Barnola J-M, Fischer H, Masson-Delmotte V, Jouzel J (2005) Stable carbon cycle-climate relationship during the late Pleistocene.

Science 310:1313-1317

[2006-06-20: ftp://ftp.ncdc.noaa.gov/pub/data/paleo/icecore/antarctica/epica_domec/edc-co2-650k-390k.txt]

Sigman DM, Boyle EA (2000) Glacial/interglacial variations in atmospheric carbon dioxide. Nature 407:859869

Simmons IG (1996) Changing the Face of the Earth: culture, environment, history. Blackwell, Oxford

Sitch S, Smith B, Prentice IC, Arneth A, Bondeau A, Cramer W, Kaplan JO, Levis S, Lucht W, Sykes MT, Thonicke K, Venevsky S (2003) Evaluation of ecosystem dynamics, plant geography and terrestrial carbon cycling in the LPJ dynamic global vegetation model. Global Change Biology 9:161-185

Sugita S, Gaillard M-J, Broström A (1999) Landscape openness and pollen records: a simulation approach. The Holocene 9:409-421

Sundquist ET (1993) The global carbon dioxide budget. Science 259:934-941

Thompson LG, Moosley-Thompson E, Davis ME, Linn P-N, Henderson K, Mashiotta TA (2003) Tropical glacier and ice core evidence of climate change on annual to millennial time scales. Climatic Change 59:137-155

Thonicke K, Venevsky S, Sitch S, Cramer W (2001) The role of fire disturbance for global vegetation dynamics: coupling fire into a Dynamic Global Vegetation Model. Global Ecology \& Biogeography 10:661-677

Tinker PB, Ingram JSI, Struwe S (1996) Effects of slash-and-burn agriculture and deforestation on climate change. Agriculture, Ecosystems and Environment 58:13-22

Trenberth KE, Dai AG, Rasmussen RM, Parsons DB (2003) The changing character of precipitation. Bulletin of the American Meteorological Society 84:1205-1217

Turner II BL, Clark WC, Kates RW, Richards JF, Mathews JT, Meyer WB (eds) (1990) The Earth as transformed by Human Action. Cambridge University Press, Cambridge

U.S. Census Bureau (2006) [2006-06-15: http://www.census.gov/main/www/popclock.html]

van Hoof TB, Bunnik FPM, Waucomont JGM, Kürschner WM, Visscher H (2006) Forest re-growth on medieval farmland after the Black Death pandemic - Implications for atmospheric $\mathrm{CO}_{2}$ levels.

Palaeogeography, Palaeoclimatology, Palaeoecology 237:396-409

Vitousek PM, Mooney HA, Lubchenco J, Melillo JM (1997) Human domination of Earth’s ecosystems. Science 277:494-499

Wang Y, Mysak LA, Roulet NT (2005) Holocene climate and carbon cycle dynamics: Experiments with the “green” McGill Paleoclimate Model. Global Biogeochemical Cycles 19:GB3022 DOI 10.1029/2005GB002484

Whitlock C, Bartlein P (2004) Holocene fire activity as a record of past environmental change. Developments In Quaternary Science 1:479-490

Williams M (2000) Dark ages and dark areas: global deforestation in the deep past. Journal of Historical Geography 26:28-46

Williams M (2003) Deforesting the Earth: From Prehistory to Global Crisis. University of Chicago Press, Chicago

Wolff EW (2005) Understanding the past - climate history from Antarctica. Antarctic Science 17:487-495 
Woodward FI (1987) Stomatal numbers are sensitive to increases in $\mathrm{CO}_{2}$ from pre-industrial levels. Nature 327:617-618

Zaehle S, Sitch S, Smith B, Hatterman F (2005) Effects of parameter uncertainties on the modelling of terrestrial biosphere dynamics. Global Biogeochemical Cycles 19:GB3020 DOI 10.1029/2004GB002395

Zielinski G (2000) Use of paleo-records in determining variability within the volcanism-climate system. Quaternary Science Reviews 19:417-438

Zobler L (1986) A world soil file for global climate modelling. NASA Technical Memorandum, 87802, 32 



\section{Data of areas assigned agriculture per continent during each time-slice}

Table A1. Area assigned permanent agriculture per continent and time-slice. [1000 km²]

\begin{tabular}{lrrrrrrr}
\hline Time-slice & Africa & Asia & Australia & Europe & N Am. & S\&C Am. & Total \\
\hline a) & 31 & 87 & 0 & 0 & 0 & 0 & 118 \\
b) & 31 & 516 & 0 & 0 & 0 & 87 & 634 \\
c) & 281 & 1548 & 0 & 812 & 0 & 164 & 2805 \\
d) & 392 & 1366 & 0 & 1579 & 0 & 201 & 3538 \\
e) & 1553 & 2580 & 299 & 1812 & 68 & 1008 & 7320 \\
f) & 3151 & 6744 & 1398 & 2746 & 607 & 2017 & 16664 \\
g) & 9355 & 13333 & 4462 & 4523 & 3949 & 5968 & 41590 \\
\hline
\end{tabular}

Table A2. Area assigned non-permanent agriculture per continent and time-slice. [1000 km²]

\begin{tabular}{lrrrrrrr}
\hline Time-slice & Africa & Asia & Australia & Europe & N. Am. & S\&C Am. & Total \\
\hline a) & 3 & 1619 & 0 & 2438 & 0 & 5 & 4066 \\
b) & 185 & 2815 & 0 & 2650 & 0 & 69 & 5719 \\
c) & 348 & 2867 & 0 & 2226 & 17 & 70 & 5528 \\
d) & 373 & 2715 & 0 & 1674 & 20 & 82 & 4864 \\
e) & 223 & 1538 & 0 & 1080 & 35 & 53 & 2930 \\
f) & 870 & 2331 & 0 & 1606 & 600 & 248 & 5655 \\
g) & 2819 & 1434 & 123 & 0 & 5 & 1020 & 5401 \\
\hline
\end{tabular}





\section{APPENDIX B}

\section{Calculation of the pre-industrial $\mathrm{CO}_{2}$ concentration}

The atmospheric $\mathrm{CO}_{2}$ concentration was set to a constant value during the entire simulation period, except during the last 98 years (see Section 3.4). The pre-industrial value is commonly referred to be about 280 ppmv (Prentice et al. 2001) and is often used as this constant value in modelling studies covering the Holocene.

However, when analysing the $\mathrm{CO}_{2}$ data measured in Antarctic ice cores from Indermühle et al. (1999) and Monnin et al. (2004) for the 6000 years before the onset of the industrial revolution, graphically displayed in Figure B1, it is noticeable that the 280-ppmv level is not a representative average value for the time-period of interest in this particular study.

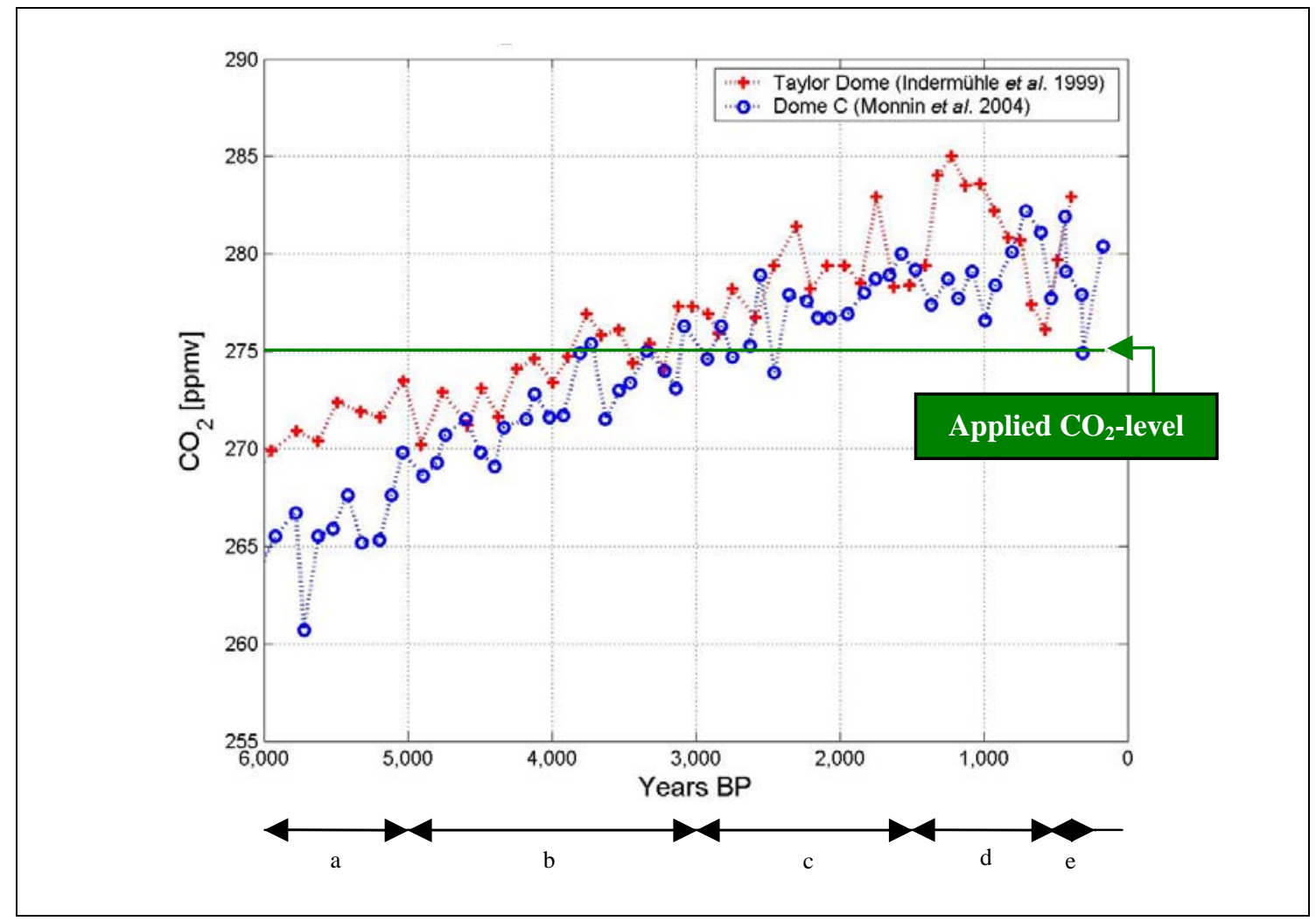

Figure B1. Atmospheric $\mathrm{CO}_{2}$ concentration 5944 to 173 years BP, adapted from Indermühle et al. (1999) and Monnin et al. (2004) [ppmv]. The first five time-slices (a-e) are indicated below the graph.

After calculating simple as well as weighted average values for the two time-series (Table B1), a $\mathrm{CO}_{2}$ level of 275 ppmv was applied as a representative level to be used (Figure B1).

Table B1. Average $\mathrm{CO}_{2}$ concentration 5944 to 173 years BP. [ppmv]

\begin{tabular}{lcc}
\hline & Taylor Dome & Dome C \\
\hline Simple average & 276.8 & 274.1 \\
Weighted average & 276.1 & 273.9 \\
\hline
\end{tabular}

The data sets with measured $\mathrm{CO}_{2}$ concentration from Indermühle et al. (1999) and Monnin et al. (2004) for the last 6000 years are displayed in Table B2. 
Table B2. Measured $\mathrm{CO}_{2}$ concentration $5944 \mathrm{BP}-173$ years BP at Taylor Dome and Dome C.

\begin{tabular}{|c|c|c|c|c|c|c|c|c|c|}
\hline \multicolumn{4}{|c|}{ Taylor Dome } & \multicolumn{6}{|c|}{ Dome C } \\
\hline $\begin{array}{c}\text { Year } \\
\text { BP }\end{array}$ & $\begin{array}{c}\mathrm{CO}_{2} \\
\text { [ppmv] }\end{array}$ & $\begin{array}{c}\text { Year } \\
\text { BP }\end{array}$ & $\begin{array}{c}\mathrm{CO}_{2} \\
\text { [ppmv] }\end{array}$ & $\begin{array}{c}\text { Year } \\
\text { BP }\end{array}$ & $\begin{array}{c}\mathrm{CO}_{2} \\
{[p p m v]}\end{array}$ & $\begin{array}{c}\text { Year } \\
\text { BP }\end{array}$ & $\begin{array}{c}\mathrm{CO}_{2} \\
\text { [ppmv] }\end{array}$ & $\begin{array}{c}\text { Year } \\
\text { BP }\end{array}$ & $\begin{array}{c}\mathrm{CO}_{2} \\
{[\mathrm{ppmv}]}\end{array}$ \\
\hline 390 & 282.9 & 3021 & 277.3 & 173 & 280.4 & 2453 & 273.9 & 4895 & 268.6 \\
\hline 486 & 279.7 & 3118 & 277.3 & 311 & 274.9 & 2550 & 278.9 & 5033 & 269.8 \\
\hline 573 & 276.1 & 3221 & 274.1 & 322 & 277.9 & 2625 & 275.3 & 5114 & 267.6 \\
\hline 670 & 277.4 & 3320 & 275.4 & 427 & 279.1 & 2743 & 274.7 & 5196 & 265.3 \\
\hline 742 & 280.7 & 3435 & 274.4 & 435 & 281.9 & 2820 & 276.3 & 5318 & 265.2 \\
\hline 830 & 280.8 & 3533 & 276.1 & 530 & 277.7 & 2918 & 274.6 & 5419 & 267.6 \\
\hline 924 & 282.2 & 3653 & 275.8 & 604 & 281.1 & 3078 & 276.3 & 5521 & 265.9 \\
\hline 1020 & 283.6 & 3758 & 276.9 & 709 & 282.2 & 3138 & 273.1 & 5621 & 265.5 \\
\hline 1125 & 283.5 & 3890 & 274.7 & 806 & 280.1 & 3219 & 274.0 & 5721 & 260.7 \\
\hline 1220 & 285.0 & 3990 & 273.4 & 917 & 278.4 & 3337 & 275.0 & 5780 & 266.7 \\
\hline 1319 & 284.0 & 4121 & 274.6 & 991 & 276.6 & 3454 & 273.4 & 5921 & 265.5 \\
\hline 1406 & 279.4 & 4243 & 274.1 & 1083 & 279.1 & 3531 & 273.0 & & \\
\hline 1513 & 278.4 & 4368 & 271.6 & 1175 & 277.7 & 3628 & 271.5 & & \\
\hline 1620 & 278.3 & 4484 & 273.1 & 1249 & 278.7 & 3724 & 275.4 & & \\
\hline 1745 & 282.9 & 4583 & 271.2 & 1362 & 277.4 & 3802 & 274.9 & & \\
\hline 1853 & 278.5 & 4757 & 272.9 & 1477 & 279.2 & 3921 & 271.7 & & \\
\hline 1965 & 279.4 & 4909 & 270.2 & 1574 & 280.0 & 4019 & 271.6 & & \\
\hline 2084 & 279.4 & 5031 & 273.5 & 1653 & 278.9 & 4117 & 272.8 & & \\
\hline 2203 & 278.2 & 5193 & 271.6 & 1751 & 278.7 & 4176 & 271.5 & & \\
\hline 2302 & 281.4 & 5327 & 271.9 & 1830 & 278.0 & 4335 & 271.1 & & \\
\hline 2453 & 279.4 & 5488 & 272.4 & 1948 & 276.9 & 4395 & 269.1 & & \\
\hline 2581 & 276.7 & 5620 & 270.4 & 2069 & 276.7 & 4496 & 269.8 & & \\
\hline 2742 & 278.2 & 5774 & 270.9 & 2150 & 276.7 & 4596 & 271.5 & & \\
\hline 2841 & 275.9 & 5944 & 269.9 & 2228 & 277.6 & 4737 & 270.7 & & \\
\hline 2912 & 276.9 & & & 2352 & 277.9 & 4797 & 269.3 & & \\
\hline
\end{tabular}

\section{Data references}

Taylor Dome from Indermühle et al. (1999)

Indermühle A, Stocker TF, Joos F, Fischer H, Smith HJ, Wahlen M, Deck B, Mastroianni D (1999) Holocene carbon-cycle dynamics based on $\mathrm{CO}_{2}$ trapped in ice at Taylor Dome, Antarctica. Nature 398:121-126

[2005-11-18: ftp://ftp.ngdc.noaa.gov/paleo/icecore/antarctica/taylor/taylor_co2-holocene.txt]

Dome C from Monnin et al. (2004)

Monnin E, Steig EJ, Siegenthaler U, Kawamura K, Schwander J, Stauffer B, Stocker TF, Morse DL, Barnola JM, Bellier B, Raynaud D, Fischer H (2004) Evidence for substantial accumulation rate variability in Antarctica during the Holocene, through synchronization of $\mathrm{CO}_{2}$ in the Taylor Dome, Dome $\mathrm{C}$ and DML ice cores. Earth and Planetary Science Letters 224:45-54

[2005-11-18: http://www1.ncdc.noaa.gov/pub/data/paleo/icecore/antarctica/epica_domec/edc-co2.txt] 


\section{Resulting simulated carbon flux per continent during each time-slice}

Table C1. Simulated carbon flux from permanent agriculture per continent and per time-slice. [GtC]

\begin{tabular}{lrrrrrrr}
\hline Time-slice & Africa & Asia & Australia & Europe & N Am & S\&C Am & Total \\
\hline a) & 0.0 & 0.1 & 0.0 & 0.0 & 0.0 & 0.0 & 0.1 \\
b) & 0.0 & 1.4 & 0.0 & 0.0 & 0.0 & 0.6 & 1.9 \\
c) & 1.0 & 6.6 & 0.0 & 7.2 & 0.0 & 0.6 & 15.3 \\
d) & 0.2 & 2.1 & 0.0 & 7.4 & 0.0 & 0.4 & 10.1 \\
e) & 7.1 & 4.0 & 1.6 & 1.8 & 1.0 & 9.8 & 25.3 \\
f) & 6.3 & 20.8 & 2.2 & 5.1 & 6.3 & 9.9 & 50.6 \\
g) & 20.0 & 16.7 & 2.1 & 8.1 & 16.8 & 37.7 & 101.5 \\
\hline
\end{tabular}

Table C2. Simulated carbon flux from non-permanent agriculture per continent and time-slice. [GtC]

\begin{tabular}{lrrrrrrr}
\hline Time-slice & Africa & Asia & Australia & Europe & N Am & S\&C Am & Total \\
\hline a) & 0.0 & 0.9 & 0.0 & 2,6 & 0.0 & 0.0 & 3.5 \\
b) & 0.3 & 2.6 & 0.0 & 1.8 & 0.0 & 0.1 & 4.7 \\
c) & 0.7 & 4.8 & 0.0 & 2.6 & 0.0 & 0.1 & 8.2 \\
d) & 0.6 & 4.8 & 0.0 & 2.8 & 0.0 & 0.2 & 8.3 \\
e) & 0.7 & -0.2 & 0.0 & 1.8 & 0.4 & 0.2 & 2.8 \\
f) & 1.8 & 5.8 & -0.8 & 4.1 & 4.1 & -1.6 & 13.4 \\
g) & 21.2 & 6.4 & 1.1 & -5.4 & -2.0 & 8.1 & 29.5 \\
\hline
\end{tabular}



Lunds Universitets Naturgeografiska institution. Seminarieuppsatser. Uppsatserna finns tillgängliga på Naturgeografiska institutionens bibliotek, Sölvegatan 12, 22362 LUND. Serie startade 1985.

The reports are available at the Geo-Library, Department of Physical Geography, University of Lund, Sölvegatan 12, S-223 62 Lund, Sweden.

Report series started 1985.

79. Ullman, M., (2001): El Niño Southern Oscillation och dess atmosfäriska fjärrpåverkan.

80. Andersson, A., (2001): The wind climate of northwestern Europe in SWECLIM regional climate scenarios.

81. Lalloo, D., (2001): Geografiska informationssystem för studier av polyaromatiska kolväten (PAH) - Undersökning av djupvariation i BO01-området, Västra hamnen, Malmö, samt utveckling av en matematisk formel för beräkning av PAHkoncentrationer från ett kontinuerligt utsläpp.

82. Almqvist, J., Fergéus, J., (2001): GIS-implementation in Sri Lanka.

Part 1: GIS-applications in Hambantota district Sri Lanka : a case study.

Part 2: GIS in socio-economic planning : a case study.

83. Berntsson, A., (2001): Modellering av reflektans från ett sockerbetsbestånd med hjälp av en strålningsmodell.

84. Umegård, J., (2001): Arctic aerosol and long-range transport.

85. Rosenberg, R., (2002): Tetratermmodellering och regressionsanalyser mellan topografi, tetraterm och tillväxt hos sitkagran och lärk - en studie i norra Island.

86. Håkansson, J., Kjörling, A., (2002): Uppskattning av mängden kol i trädform - en metodstudie.

87. Arvidsson, H., (2002): Coastal parallel sediment transport on the SE Australian inner shelf - A study of barrier morphodynamics.

88. Bemark, M., (2002): Köphultssjöns tillstånd och omgivningens påverkan.

89. Dahlberg, I., (2002): Rödlistade kärlväxter i Göteborgs innerstad - temporal och rumslig analys av rödlistade kärlväxter i Göteborgs artdataarkiv, ADA.

90. Poussart, J-N., (2002): Verification of Soil Carbon Sequestration - Uncertainties of Assessment Methods.

91. Jakubaschk, C., (2002): Acacia senegal, Soil Organic Carbon and Nitrogen Contents: A Study in North Kordofan, Sudan.

92. Lindqvist, S., (2002): Skattning av kväve i gran med hjälp av fjärranalys.

93. Göthe, A., (2002): Översvämningskartering av Vombs ängar.

94. Lööv, A., (2002): Igenväxning av Köphultasjö - bakomliggande orsaker och processer.

95. Axelsson, H., (2003): Sårbarhetskartering av bekämpningsmedels läckage till grundvattnet - Tillämpat på vattenskyddsområdet Ignaberga-Hässleholm.

96. Hedberg, M., Jönsson, L., (2003): Geografiska Informationssystem på Internet - En webbaserad GIS-applikation med kalknings- och försurningsinformation för Kronobergs län.

97. Svensson, J., (2003): Wind Throw Damages on Forests - Frequency and Associated Pressure Patterns 1961-1990 and in a Future Climate Scenario.

98. Stroh, E., (2003): Analys av fiskrättsförhållandena i Stockholms skärgård i relation till känsliga områden samt fysisk störning.

99. Bäckstrand, K., (2004): The dynamics of non-methane hydrocarbons and other trace gas fluxes on a subarctic mire in northern Sweden. 
100. Hahn, K., (2004): Termohalin cirkulation i Nordatlanten.

101. Lina Möllerström (2004): Modelling soil temperature \& soil water availability in semi-arid Sudan: validation and testing.

102. Setterby, Y., (2004): Igenväxande hagmarkers förekomst och tillstånd i Västra Götaland.

103. Edlundh, L., (2004): Utveckling av en metodik för att med hjälp av lagerföljdsdata och geografiska informationssystem (GIS) modellera och rekonstruera våtmarker i Skåne.

104. Schubert, P., (2004): Cultivation potential in Hambantota district, Sri Lanka

105. Brage, T., (2004): Kvalitetskontroll av servicedatabasen Sisyla

106. Sjöström., M., (2004): Investigating Vegetation Changes in the African Sahel 19822002: A Comparative Analysis Using Landsat, MODIS and AVHRR Remote Sensing Data

107. Danilovic, A., Stenqvist, M., (2004): Naturlig föryngring av skog

108. Materia, S., (2004): Forests acting as a carbon source: analysis of two possible causes for Norunda forest site

109. Hinderson, T., (2004): Analysing environmental change in semi-arid areas in Kordofan, Sudan

110. Andersson, J., (2004): Skånska småvatten nu och då - jämförelse mellan 1940, 1980 och 2000-talet

111. Tränk, L., (2005): Kadmium i skånska vattendrag - en metodstudie i föroreningsmodellering.

112. Nilsson, E., Svensson, A.-K., (2005): Agro-Ecological Assessment of Phonxay District, Luang Phrabang Province, Lao PDR. A Minor Field Study.

113. Svensson, S., (2005): Snowcover dynamics and plant phenology extraction using digital camera images and its relation to CO2 fluxes at Stordalen mire, Northern Sweden.

114. Barth, P. von., (2005): Småvatten då och nu. En förändringsstudie av småvatten och deras kväveretentionsförmåga.

115. Areskoug, M., (2005): Planering av dagsutflykter på Island med nätverkanalys

116. Lund, M., (2005): Winter dynamics of the greenhouse gas exchange in a natural bog.

117. Persson, E., (2005): Effect of leaf optical properties on remote sensing of leaf area index in deciduous forest.

118. Mjöfors, K., (2005): How does elevated atmospheric CO2 concentration affect vegetation productivity?

119. Tollebäck, E.,(2005): Modellering av kväveavskiljningen under fyra år i en anlagd våtmark på Lilla Böslid, Halland

120. Isacsson, C., (2005): Empiriska samband mellan fältdata och satellitdata - för olika bokskogområden i södra Sverige.

121. Bergström, D., Malmros, C., (2005): Finding potential sites for small-scale Hydro Power in Uganda: a step to assist the rural electrification by the use of GIS

122. Magnusson, A., (2005): Kartering av skogsskador hos bok och ek i södra Sverige med hjälp av satellitdata.

123. Levallius, J., (2005): Green roofs on municipal buildings in Lund - Modeling potential environmental benefits.

124. Florén, K., Olsson, M., (2006): Glacifluviala avlagrings- och erosionsformer I sydöstra Skåne - en sedimentologisk och geomorfologisk undersökning.

125. Liljewalch-Fogelmark, K., (2006): Tågbuller i Skåne - befolkningens exponering.

126. Irminger Street, T., (2006): The effects of landscape configuration on species 
richness and diversity in semi-natural grasslands on Öland - a preliminary study.

127 Karlberg, H., (2006): Vegetationsinventering med rumsligt högupplösande satellitdata - en studie av QuickBirddata för kartläggning av gräsmark och konnektivitet i landskapet.

128 Malmgren, A., (2006): Stormskador. En fjärranalytisk studie av stormen Gudruns skogsskador och dess orsaker.

129 Olofsson, J., (2006): Effects of human land-use on the global carbon cycle during the last 6000 years. 